Article

\title{
The Narrative Abilities of an English-Spanish Bilingual with Prader-Willi Syndrome
}

\author{
Estela García-Alcaraz \\ Department of Modern Languages and Literatures, University of Ottawa, Hamelin Hall, 2nd floor, \\ 70 Laurier Ave. East, Ottawa, ON K1N 6N5, Canada; egarcia@uottawa.ca
}

Received: 21 February 2018; Accepted: 18 June 2018; Published: 2 July 2018

\begin{abstract}
The aim of this study was to analyze the narrative abilities of a 33-year-old English-Spanish bilingual with Prader-Willi syndrome (PWS). The few previous linguistic studies examining monolinguals with PWS have focused primarily on these individuals' narrative capacity, revealing a performance deficit in this area (Lewis et al. 2002; Garayzábal-Heinze et al. 2012). The present study is novel in that it examines a bilingual speaker and also tests his narrative abilities in both languages. Two wordless picture books from Mayer's $(1967,1969)$ Frog story series were used as the elicitation method. The PWS bilingual produced, over two experimental sessions, four narratives (two in each language), which were compared to four analogous narratives produced by a 25-year-old typically developing bilingual with a comparable linguistic background and proficiency level in Spanish and English. Following Gonçalves and collaborators' (Gonçalves et al. 2001a, 2001b, 2001c) narrative evaluation protocol, the narratives were analyzed according to three dimensions: narrative structure and coherence, narrative process and complexity, and narrative content and multiplicity. Overall, the results revealed that the PWS bilingual (1) presented a poor narration ability in both languages, with narrative content and multiplicity being the least impaired; (2) showed better narrative abilities during the second experimental session (i.e., narrative abilities improved with experience/practice); and (3) did not show typically developing behavior but a comparable performance to that of monolingual speakers with PWS. These findings suggest that bilingualism should not be discouraged in PWS populations and that special attention should be given to the development of their narrative abilities in their school curriculum.
\end{abstract}

Keywords: bilingualism; developmental disabilities; Prader-Willi syndrome; narrative abilities

\section{Introduction}

Individuals with developmental and intellectual disabilities (henceforth DDs and IDs, respectively) are often discouraged from learning two languages simultaneously or from having access to a second language (henceforth L2) under the assumption that this will have a negative effect on the linguistic development of their first language (henceforth L1) (Paradis et al. 2011). This practice not only denies these individuals the possibility of becoming bilingual, but also-in all probability-the option of taking advantage of the general benefits associated with bilingualism (which are discussed in Section 1.1). Now, however, there is a growing body of research focusing on bilingualism in individuals with special needs that is not only questioning this practice but pointing out a completely opposite scenario (i.e., the encouragement of bilingualism and multilingualism). It is undeniable that there are valuable data provided by previous studies that have focused on bilingualism in individuals with DDs; nevertheless, this line of research has been narrowed to Specific Language Impairment (SLI), Autism Spectrum Disorders (ASD), and Down syndrome (DS) (see Kay-Raining Bird et al. 2016 for a complete overview). Thus, in order to have a more comprehensive view of bilingualism in non-typically developing (henceforth non-TD) individuals, it is imperative to expand the focus to other syndromes 
and conditions, as is the case with the emerging studies on bilingualism in Williams syndrome (Perovic and Lochet 2015). Accordingly, this study seeks to contribute to this developing field by providing new data from a bilingual speaker with PWS, an understudied DD. In this paper, I analyze the narrative abilities of an English-Spanish bilingual with PWS in both languages in comparison with a typically developing (henceforth TD) English-Spanish bilingual of similar age and sociolinguistic background.

\subsection{Bilingualism in Typically Developing Individuals}

Even though nowadays it seems that being bilingual is more of an asset than a problem, this has not always been the case. From the early 1920s, when the first studies focused on bilingualism and cognition arose, to the early 1960s, when Peal and Lambert's (1962) revolutionary research work was published, researchers expounded bilingualism's negative effects on intellectual abilities. Studies from this 40-year-period systematically reported the inferior linguistic abilities of bilinguals when compared to monolinguals. As Diaz (1983) and Hakuta and Diaz (1985) summarized, this bilingual disadvantage was mainly reflected in deficient articulation (Carrow 1957), poor vocabulary (Barke and Williams 1938), poor writing skills, and a greater number of grammatical errors (Harris 1948). However, while in verbal tasks researchers repeatedly showed either a bilingual disadvantage or a neutral effect, contradictory findings were found for non-verbal experiments (see Peal and Lambert 1962; Diaz 1983 for a complete review). With the publication of Peal and Lambert's (1962) seminal work, the reliability of previous findings started to be questioned, since, for the first time, a balanced bilingual group matching in terms of class, sex, and age to those of a monolingual group was included in a study (Canadian English-French bilinguals compared to Canadian monolingual French speakers). This special attention to participant selection was crucial as the careless criteria used to determine bilingualism in previous studies could have influenced the negative results obtained for bilinguals. For example, Brunner (1929) determined levels of bilingualism in terms of parents' origin, which today is known to not be a very precise method of determining the degree of bilingualism. Peal and Lambert's results showed that when participants were carefully selected, bilinguals showed an advantage over monolinguals in both verbal and non-verbal tasks. Nevertheless, these findings were not free from controversy and some researchers pointed out that the positive results for bilingualism obtained could have been the result of an involuntary bilingual bias. The authors, in an attempt to include only balanced bilinguals, could have favored the positive effects of bilingualism because they only included bilinguals who obtained a certain result in the intelligence test administered (see Hakuta and Diaz 1985, pp. 322-23, for a complete review of the possible bilingual bias in this study). Be that as it may, since the early 1960s a substantial body of research has revealed that bilingualism seems to lead to different cognitive benefits.

Following Adescope et al.'s (2010) comprehensive review of previous work focused on the cognitive effects of bilingualism, bilinguals appear to have: better attentional control in non-verbal tasks (Bialystok 2001; Emmorey et al. 2008); greater metalinguistic awareness (Galambos and Goldin-Meadow 1990; Yelland et al. 1993) and metacognitive awareness ${ }^{1}$ (Ransdell et al. 2006); better optimization of the working memory capacity (Bialystok et al. 2004; Morales et al. 2013); better management of problem-solving skills (Bialystok 1999, 2006); superior abstract or symbolic analysis capacity (Cummins 1976); greater creative thinking (Ricciardelli 1992; Baker 2001); and more diverse communication strategies (Thomas 1992). Recently, different studies have revealed an interaction between bilingualism and certain narrative abilities in both TD and non-TD individuals. Andreou (2015) analyzed the narrative performance of TD bilingual children at the microstructural (morphosyntactic abilities) and macrostructural (coherence and global organization abilities) levels. Her results showed, on the one hand, that bilinguals outperformed monolinguals at a macrostructural level and, on the other hand, that bilingual children developed better global narrative

1 While metalinguistic awareness refers to the ability to think about the language, metacognitive awareness refers to the capacity to reflect on the learning process itself. 
abilities earlier than their monolingual counterparts ( 9 vs. 11 years old approximately). Better narrative abilities at macrostructural level were also found in bilinguals with SLI (Tsimpli et al. 2016) and with high-functioning autism (Baldimtsi et al. 2016) when compared to their monolingual peers. In addition, studies from the last decade have revealed that bilingualism seems to delay the age of onset of dementia and cognitive aging (Bialystok et al. 2007; Bialystok and Craik 2010). Finally, one obvious, but often undervalued, benefit of bilingualism in scientific research is the intrinsic capacity to communicate and interact in two languages (or more in the case of multilingualism) and all the social benefits associated with it. Being bilingual gives a person the opportunity to have access to another language, to its culture, and, most importantly, to the speakers of that language. In the end, humans are social beings wanting to socialize and be part of a community.

\subsection{Bilingualism in Individuals with Developmental and Intellectual Disabilities}

Despite the large number of benefits to becoming bilingual, populations with DDs have been discouraged from being raised bilingual or from studying an L2 for fear of increasing their linguistic learning challenges (Cleave et al. 2014). Nevertheless, cases of bilingualism have been attested in individuals with DS (Kay-Raining Bird et al. 2016), ASD (Seung et al. 2006), or SLI (Sanz-Torrent et al. 2008), to name a few, and it is precisely these three conditions on which previous research investigating DDs and bilingualism has almost exclusively focused. Since the aim of this study is to analyze the narrative abilities of a bilingual with PWS, the revision of previous findings is primarily focused on DS. The reason for this is that within the heterogeneity of DDs, PWS and DS are, in principle, closer than PWS and SLI or PWS and ASD. As Cimolin et al. (2010, p. 1) state, "Prader-Willi and Down syndrome are two different chromosomal disorders characterized by some common clinical features, such as obesity, muscular hypotonia, ligament laxity, and mental retardation". SLI differs from DS and PWS in that it is a language disorder "diagnosed when a child's language development is deficient for no obvious reason" (Bishop 2006, p. 217), or, in other words, when it "cannot be explained in terms of mental or physical handicap, hearing loss, emotional disorder, or environmental deprivation" (Bishop 1992, p. 3). Thus, according to this description, individuals with SLI should display, by definition, typical non-verbal abilities and intelligence. Previous research, however, has shown that these individuals are not exempt from experiencing difficulty with some particular non-linguistic tasks, as seems to be the case with visuo-spatial short-term memory tasks (Hick et al. 2005) or mathematical tasks (Cowan et al. 2005; Mainela-Arnold et al. 2011) to name a few. ASD, for its part, is related to impairment of verbal and non-verbal communication, social interactions, and repetitive behaviors and interests (Tager-Flusberg 2004; Faras et al. 2010). Traditionally, ASD has been directly associated with intellectual disabilities, but recent research has revealed that, despite the fact that around $50 \%$ of children with an autistic disorder present intellectual disabilities, some individuals may show average or even superior intelligence (see Charman et al. 2011 for an overview).

Previous research that focused on bilinguals with DS is very scarce, and, at its beginning, was based on case study research, which, interestingly enough, revealed homogeneous outcomes: the possibility of becoming bilingual, or even multilingual, and facing the same language difficulties in the different languages. For example, Vallar and Papagno (1993) studied a 23-year-old L1 Italian woman with DS who was also fluent in English (and French to a lesser extent). The authors focused on vocabulary acquisition and their results revealed that the participant's phonological short-term memory appeared to not be impaired, and, in fact, seemed to facilitate the process of vocabulary acquisition. For their part, Woll and Grove (1996) studied the case of two bimodal, bilingual identical twins (English-British Sign Language) with DS whose parents were deaf. These twins were administered different verbal and non-verbal tests and their spontaneous production was analyzed in both languages. The results evidenced that the twins were fluent when signing and that the shortcomings detected were consistent across the two language modalities.

According to Kohnert and Medina (2009) and the recent exhaustive bibliography review by Kay-Raining Bird et al. (2016), apart from case studies, only five group studies analyzing bilingualism 
in DS have been carried out ${ }^{2}$. It must be stressed that four out of these five studies were conducted by the same group of researchers and that the participants partially overlapped, with English-French being almost the only bilingual language combination under analysis (see Kay-Raining Bird et al. 2016, p. 7).

Trudeau et al. (2011) carried out a cross-sectional and a longitudinal study with 18 sequential English-French bilinguals with DS. They investigated both expressive and receptive vocabulary in English (L1) and French (L2) and found that the bilinguals' French vocabulary was smaller and had greater variability than their English vocabulary but that it became more uniform as their overall vocabulary size increased. The longitudinal study showed that, while in English a vocabulary growth was detected over time for 13 participants, this was not the case for the L2, since only nine individuals showed progress in French. Regardless, what these results suggest is that under no circumstances did the fact of being exposed to an L2 appear to have a negative effect on the vocabulary acquisition of the L1. In order to evaluate the cognitive effects of being exposed to two languages, Edgin et al. (2011) administered a battery of cognitive tests to both English-Spanish bilinguals with DS and English monolinguals with DS (control group). Results showed parallel performance of both groups for all the measures under analysis. Likewise, Kay-Raining Bird et al. (2005) investigated the language abilities (mainly vocabulary comprehension) of eight bilinguals (English-one other language) with DS in comparison to 14 English monolinguals with DS and they found that both bilinguals and monolinguals with DS shared a similar profile. For their part, Feltmate and Bird (2008) analyzed the morphosyntactic and vocabulary abilities of eight English-French bilinguals with DS and four English monolinguals with DS. Their findings showed no detrimental effects of bilingualism (i.e., bilinguals with DS did not demonstrate linguistic deficits when compared to monolinguals with DS). Two of the aforementioned studies, Kay-Raining Bird et al. (2005) and Feltmate and Bird (2008), also included a TD bilingual group as a comparison baseline. Both studies agreed that while bilinguals with DS did not seem to perform much different from their monolingual counterparts, they did appear to have linguistic difficulties when compared to TD bilinguals. Nevertheless, Cleave et al. (2014) found that, in specific areas, bilinguals with DS did not differ greatly from TD bilinguals, as is the case of the ability to learn new words.

Overall, previous case studies and group studies consistently reveal that bilinguals with DS show different linguistic and cognitive deficiencies when compared to TD bilinguals but not when compared to their monolingual peers. Thus, these results, as well as those from other studies based on bilingualism in individuals with DDs (see Kay-Raining Bird et al. 2016), show that there seems to be no scientific foundation to deny individuals with these special needs the possibility of managing more than one language and, consequently, the opportunity to benefit from the positive cognitive outcomes that appear to derive from being bilingual.

\section{Prader-Willi Syndrome}

\subsection{Clinical Characteristics of the Prader-Willi Syndrome and their Impact on Language/Speech}

The Prader-Willi Syndrome (PWS) is a rare disease first described by Prader et al. (1956), and is not related to sex (Burd et al. 1990) or other factors such as race, social class, or geographical origin (Alexander and Hanson 1988; Butler and Thompson 2000). Genetic research has shown that PWS is rarely inherited and the recurrence risk within the same family is normally low (Buiting and Horsthemke 2006). It must be emphasized that although PWS has a relative low incidence (it affects one in every 10,000-15,000 humans) (Lewis et al. 2002; Dimitropoulos et al. 2013), it is one of the most frequent syndromes among those recognized (Alexander and Hanson 1988). In a simplistic way, the reason why this malformation occurs is related to the fact that, at conception, the crossing over that

2 Both Kohnert and Medina's (2009) and Kay-Raining Bird et al.'s (2016) reviews comprise research papers published mainly in English, and French to a lesser extent. It is possible that other studies have been published in languages other than English or French but have gone unnoticed. 
happens between the 23 paternal and the 23 maternal chromosomes, when they line up to form 46 chromosomes, is imperfect, which causes health and cognitive "abnormalities" in the individual. For example, DS, one of the genetic disorders with higher incident rates, is the result of three copies of chromosome 21. Prader-Willi Syndrome, for its part, is the result of problems in chromosome 15, which may have three main manifestations (see Cassidy et al. 2012 for a comprehensive genetic explanation): (1) Chromosomal deletion (the absence of part of the paternal chromosome 15); (2) Uniparental disomy (two maternal copies of chromosome 15); and (3) Imprinting defect (defined by (Cassidy et al. 2012, p.10), as a "defect in the genomic region that controls the imprinting process"). Chromosomal deletion affects about $75 \%$ of the PWS population, followed by Uniparental disomy, which causes about $20 \%$ of cases and, finally, by Imprinting defect, which only has about 5\% incidence (Cassidy et al. 2012; Dimitropoulos et al. 2013).

Even though there is variation in terms of the severity and outcomes, individuals with PWS present specific behavioral, physical, and cognitive characteristics. Their most salient trait is food anxiety, which normally leads to morbid obesity if their insatiable desire to eat is not controlled. They also tend to be stubborn, manipulative, and compulsive, and to experience temper tantrums as well as other behavioral issues. As for physical characteristics, they tend to be short and overweight and to have poor muscle tone (hypotonia) and idiosyncratic facial features. Likewise, intellectual disabilities (ranging from mild to moderate) and delay of language development are rather common in this population (see Greenswag and Alexander 1988; Cassidy et al. 2012 for a comprehensive review of the main characteristics of PWS). Previous studies show that PWS individuals have a mean Intellectual Coefficient (IQ) of $62.3^{3}$ (Curfs et al. 1991) and that their non-verbal IQ is normally higher than their verbal one (Dimitropoulos et al. 2013). Therefore, these results demonstrate that linguistic abilities are not one of their strengths. It should also be emphasized that both receptive and expressive language are impaired, the latter being poorer than the former (Kleppe et al. 1990; Lewis 2006). Similarly, if the Mean Length of Utterance (MLU ${ }^{4}$ ) is taken as a measure of language productivity, this linguistic skill is also commonly impaired, since PWS individuals' speech samples show shorter MLUs than those of the same age TD peers (Lewis et al. 2002; Lewis 2006).

Succinctly, as Lewis et al. (2002, pp. 287-88) and Dimitropoulos et al. (2013, p. 194) put it, PWS individuals show relative strengths in the following capacities: reading decoding, reading comprehension, receptive vocabulary, visual-spatial skills, picture completion, block design, object assembly, and long-term memory. On the other hand, they show deficiencies in short-time memory, as well as with auditory verbal processing and linear or temporal order processing skills. Additionally, PWS individuals show a poor expressive vocabulary, poor pragmatic abilities, and a considerable language delay, since their first words are produced between 18 months and six years (Lewis 2006), which contrasts with the pattern observed in TD children, who at 18 months start to produce their first signs of grammaticalization and generally by four years their core grammatical system is completed (Serra et al. 2000, p. 51).

Some clinical features of PWS, together with reduced cognitive and phonological abilities, result in some speech idiosyncrasies (Lewis et al. 2002; Lewis 2006). For example, having a narrow overjet and palatal arch, as well as an undersized jaw and some dentition problems, affects their articulatory skills. In accordance with Lewis (2006, p. 274), the principal speech-sound problems of PWS are "sound distortions and omissions, vowel errors, simplification of consonant blends, and difficulty sequencing syllables". In addition, poor muscle tone and abnormal laryngeal growth have an impact on their voice level. Akefeldt et al. (1997) studied the oral motor function, pitch level, and resonance of 11 individuals with PWS and found certain abnormal vocal features. Similar outcomes were found in Munson-Davis (1988), Kleppe et al. (1990), and Defloor et al. (2001). Likewise, nasality has

\footnotetext{
Generally, scores under 70 are considered indicators of intellectual disabilities (Koriakin et al. 2013).

MLU is a linguistic measure that expresses linguistic productivity in children. It can be measured by morphemes or words and both options are equally effective to evaluate language development (Parker and Brorson 2005).
} 
also been reported as a common characteristic of this syndrome (Branson 1981; Edmonston 1982). With regard to speech fluency, previous research has revealed that PWS individuals consistently show dysfluency. Defloor et al. (2000) studied the speech fluency of 15 PWS individuals through four different speech modalities (spontaneous, repetition, monologue, and automatic series) and their results revealed "within-word dysfluencies such as part-word repetitions, whole-word repetitions, blocks, prolongations, and broken words" (Defloor et al. 2000, p. 95). These authors defended that these dysfluencies did not obey to stuttering and/or cluttering, but to cognitive and language deficits, a position also defended by Branson (1981); Kleppe et al. (1990); and Lewis (2006).

In sum, previous research on PWS has mainly focused on its clinical, cognitive, and behavioral characteristics while its linguistic abilities have received little attention. Overall, linguistic research has focused on two main topics: speech characteristics and narrative abilities. Having presented an overview of the main findings related to speech characteristics, in the next section I will concentrate on the narrative abilities of the PWS population. I will first provide an overview of the narrative framework that forms this study and I will subsequently scrutinize the narrative abilities of monolingual speakers with PWS.

\subsection{Narrative Abilities in Prader-Willi Syndrome}

One of the most frequent activities in a person's daily life, to a greater or lesser extent, consists in narrating personal events (Fivush and Nelson 2004; Gonçalves et al. 2011), a capacity that emerges at a very young age as a way to organize human experience (Bruner 1990) and that does not differ significantly from the way fictitious stories are narrated (Anderson and Conway 1993). Given that narrating is a very common and familiar activity for all of us, we might be inclined to believe that it is a relatively simple and straightforward task. Nonetheless, the reality is that narrating properly, either personal or invented stories, is a highly demanding task that entails the integration of linguistic, cognitive, and social domains (Tsimpli et al. 2016). Thus, given the complexity of this activity, even for TD individuals, it should not be surprising that PWS individuals show consistent deficiencies in this respect, as will be detailed later in this section. Children and adult's narrative productions have been extensively used by linguistic researchers to analyze the writer/speakers' narrative abilities and/or their linguistic competence or productivity. It is worth noting that while there are different reliable analysis proposals to evaluate the quality of written or oral narratives produced by TD individuals, the options specifically conceived to analyze the narrative production of individuals with special needs are more limited. In this study, I follow Gonçalves and collaborators' narrative evaluation scheme (Gonçalves et al. 2001a, 2001b, 2001c), which consists in the analysis of three dimensions (narrative structure and coherence, narrative process and complexity, and narrative content and multiplicity), and their corresponding subdimensions, which are presented in Table 1 following the authors' description.

This methodology was originally conceived to evaluate the narrative abilities of individuals with psychological disorders and its reliability was satisfactorily tested in patients with agoraphobia (Gonçalves et al. 2002). Subsequently, it was extended to the assessment of the narrative abilities in individuals with neurodevelopmental disorders such as Williams syndrome, Smith-Magenis syndrome, and PWS (Gonçalves et al. 2011; Garayzábal-Heinze et al. 2012). 
Table 1. Gonçalves et al.'s (2001a, 2001b, 2001c) narrative guidelines by dimensions and subdimensions.

\begin{tabular}{|c|c|}
\hline \multicolumn{2}{|c|}{ Narrative Structure and Coherence } \\
\hline 1. Orientation & Reference to the circumstances that surround an action. \\
\hline 2. Structural sequence & Events are presented in a logical sequence. \\
\hline 3. Evaluative commitment & The narrator shows emotional involvement. \\
\hline 4. Integration & The narrative is presented in an integrated way (it makes sense). \\
\hline \multicolumn{2}{|c|}{ Narrative Process and Complexity } \\
\hline 1. Objectifying & Sensorial information is included. \\
\hline 2. Emotional subjectifying & Reference to emotional states is included. \\
\hline 3. Cognitive subjectifying & The narrator's thoughts are included. \\
\hline 4. Metaphorizing & Metaphors are included. \\
\hline \multicolumn{2}{|c|}{ Narrative Content and Multiplicity } \\
\hline 1. Themes & Variety of themes/topics is included. \\
\hline 2. Events & Variety of events/actions is included. \\
\hline 3. Scenarios & Explicit reference to the atmosphere that surrounds an action. \\
\hline 4. Characters & Variety of characters is included. \\
\hline
\end{tabular}

It is important to highlight that although a great deal of individual variability exists between the PWS population, some common idiosyncratic narrative features have been identified in previous studies. Lewis et al. (2002) and Garayzábal-Heinze et al. (2012), using different techniques and narrative analysis, studied the narrative abilities of monolinguals with PWS. By means of a narrative retelling task, Lewis et al. (2002) investigated whether 24 participants (eight preschools, eight school-age children, and eight adolescents/adults) included the grammar components and content items presented in the original story in their own narrative production. In addition, and in order to measure the participants' comprehension capacity, participants were asked three factual and three inferential questions. Results revealed important deficits in both narrative abilities and comprehension questions in the three groups. However, these deficiencies were more evident in younger participants, which indicates that they do not disappear with age but rather improve in adulthood, which, in turn, can be interpreted as an experience/practice gain. Garayzábal-Heinze et al. (2012), for their part, compared the narrative abilities of two individuals with PWS with those observed in two individuals with Williams syndrome and two with Smith-Magenis syndrome (all microdeletion syndromes characterized by cognitive impairment and language deficits). Using the well-known picture book Frog, Where Are You? (Mayer 1969) to elicit speech samples, participants were asked to explain the story to the examiner, who recorded the sessions. Narratives were transcribed and analyzed according to Gonçalves et al.'s (2001a, 2001b, 2001c) narrative evaluation proposal presented in Table 1. Results showed that all participants, regardless of the syndrome, exhibited poor narrative abilities to different extents. PWS individuals had the lowest performance in both the narrative structure and coherence and the narrative process and complexity dimensions, while the opposite trend was observed in the narrative content and multiplicity dimension: PWS and Williams syndrome participants obtained the highest scores. These results, together with those of Lewis et al. (2002), are evidence that narration is an arduous task for these individuals and point to the need to include this content in their school curriculum.

Since research on the linguistic abilities of individuals with PWS has been sparse and has only addressed monolingual speakers, in this study I investigate the narrative abilities of an English-Spanish bilingual with PWS in comparison to a TD English-Spanish bilingual and to the two Spanish monolingual speakers with PWS in Garayzábal-Heinze et al.'s (2012) study. The results will shed light on how the narrative abilities of a bilingual with PWS compare in the two languages and will represent a first step towards the establishment of a new line of research that may help speech therapists and other intervention professionals to make more informed decisions with regard to PWS and bilingualism. At the same time, the outcomes of this study will contribute to the line of research 
initiated by Kay-Raining Bird and collaborators focused on bilingualism in populations with IDs by providing new data from a different DD with ID and from a previously understudied language combination. This type of study is crucial since, as Garayzábal-Heinze et al. (2012, p. 49) argue, the analysis of the narrative production in non-TD individuals with IDs is of particular relevance because it is normally accompanied by an affected language system and this, in the authors' words, "could elucidate about the genetic contributions to language and narrative organization in atypical neurodevelopmental genetically based disorders".

\section{The Study}

\subsection{Research Questions}

In this study, I intend to answer the following research questions:

- $\quad$ Research question 1: Does an English-Spanish bilingual with PWS show poor narrative abilities in terms of narrative structure and coherence, narrative process and complexity, and narrative content and multiplicity as previous research has revealed in the case of monolinguals with PWS? Does the bilingual speaker show relative strength in the narrative content and multiplicity dimension compared to the other two dimensions, as Garayzábal-Heinze et al. (2012) found for monolingual Spanish speakers with PWS?

- Research question 2: Are the narrative abilities of an English-Spanish bilingual with PWS comparable in both languages?

- $\quad$ Research question 3: How are the narrative abilities of an English-Spanish bilingual with PWS compared to a TD English-Spanish bilingual?

\subsection{Participants}

One bilingual with PWS (Yves) and one TD bilingual (Olivia) $)^{5}$ participated in the study. Both participants were asked to complete a language background questionnaire. Yves is a 33-year-old male English-Spanish bilingual who was diagnosed with Prader-Willi syndrome (Chromosomal deletion) when he was 11 years old. Olivia is a 25-year-old female TD English-Spanish bilingual. Both participants were raised in Ontario (Canada) and are simultaneous English-Spanish bilinguals. In both cases, English is the dominant language and Spanish is the heritage language. They both belong to Spanish-speaking families (both parents) from Spain who maintain Spanish as the family communication language but speak predominantly English in social and professional circles. Olivia lives independently and works in an Anglophone context; Yves lives in an Anglophone group home and visits his family every other weekend. Both participants gave their consent to participate in this study, which was approved by the ethics committee of the University of Ottawa (file reference: \#06-16-19).

\subsection{Instruments}

Besides completing a language background questionnaire, both participants were asked to complete different tasks to evaluate their proficiency level in English and Spanish and their narrative abilities in both languages.

\subsubsection{Proficiency Tests}

In order to assess the participants' proficiency level in both English and Spanish, they were administered the Oxford Quick Placement Test (UCLES 2001) and a short version of the Wisconsin Spanish Placement Test (2009) (two of the most common standardized tests used in the second language acquisition field to evaluate knowledge of English and Spanish as foreign languages), as well

5 In order to preserve the participants' anonymity, the two names are fictional. 
as separate cloze tests in both English and Spanish (used extensively in the Language Acquisition Research Laboratory at the University of Ottawa). The tests' results, reported in Table 2, revealed that both participants had a high competence in both languages.

Table 2. Cloze and proficiency tests' results for Yves and Olivia.

\begin{tabular}{ccccc}
\hline Participant & $\begin{array}{c}\text { Spanish Cloze } \\
\text { Test }\end{array}$ & $\begin{array}{c}\text { English Cloze } \\
\text { Test }\end{array}$ & $\begin{array}{c}\text { Oxford Proficiency } \\
\text { Test (English) }\end{array}$ & $\begin{array}{c}\text { Wisconsin Proficiency } \\
\text { Test (Spanish) }\end{array}$ \\
\hline Yves & $20 / 20$ & $24 / 25$ & $49 / 60$ & $26 / 36$ \\
Olivia & $16 / 20$ & $24 / 25$ & $58 / 60$ & $36 / 36$ \\
\hline
\end{tabular}

In English, both participants showed $96 \%$ accuracy in the cloze test and were considered advanced speakers of English according to the results from The Oxford Quick Placement Test (Yves showed a C1 level conforming to the CEFR ${ }^{6}$ and Olivia a C2 level). In the case of Spanish, results also revealed an advanced level of proficiency, since both participants showed more than $70 \%$ of accuracy in the cloze test and in the Wisconsin Spanish Placement Test.

\subsubsection{Narrative Elicitation Tasks}

Participants were presented with two wordless picture books, A Boy, a Dog and a Frog (Mayer 1967) and Frog, Where Are You? (Mayer 1969), and were asked to explain the story to the investigator. This elicitation method, popularly known as the Frog story task, has been widely used in linguistic research in both TD and non-TD populations and for different languages (see Strömqvist and Verhoeven 2004 or Slobin 2005 for a bibliography). In both picture books, there are two main characters, a boy and his dog, that look for or try to catch a frog. Both picture books are related but are completely autonomous, since the context and the adventures the characters experience throughout the two picture books are different. In A Boy, a Dog and a Frog (25 images) (Mayer 1967), a boy and his dog are on a fishing trip and see a frog they would like to catch. The frog escapes and they both try to chase it. They finally give up and go back home, only to have the frog follow them there. The picture book Frog, Where Are You? (25 images) (Mayer 1969) shows the frog escaping from the boy's home during the night, followed by the boy and his dog searching for it in the forest. Before finding the frog, their adventure includes encounters with a variety of animals.

Taking into account the different characters involved and the different situations and contexts depicted by the images, many researchers defend and agree in considering the Frog story series as a legitimate tool to elicit narrative texts (oral and/or written). With the appropriate data analysis tools, these narratives can provide appropriate speech and written samples from which to analyze the participants' narrative abilities.

\subsection{Procedure}

Data collection took place in four sessions. In the first session, the participants were given the research project details and were both asked to orally narrate A Boy, a Dog and a Frog (Mayer 1967) in English and Frog, Where Are You? (Mayer 1969) in Spanish. The narratives were all audio recorded. During the second session, the narration languages were reversed so that $A$ Boy, a Dog and a Frog (Mayer 1967) was asked to be narrated in Spanish and Frog, Where Are You? (Mayer 1969) in English. In both sessions the task procedure was the same: participants were asked to narrate one story first and, once finished, the participant and the investigator talked about trivial things about the story they had just narrated. Once the participants felt comfortable and ready to continue, they were asked to narrate the second story. During the first experimental session participants did not have access

6 Common European Framework of Reference for Languages. 
to the pictures before starting the narrative task, but they did know the title of the story they were about to narrate. During the second experimental session, however, they knew both stories since they had already narrated them in the previous session (though in a different language). Between the first and the second sessions, there was an average of a two-and-a-half-month gap. In sessions three and four, participants completed the language background questionnaire, the two cloze tests, and the two proficiency tests previously mentioned.

\subsection{Data Treatment}

The eight oral narratives (both participants produced two narratives in Spanish and two narratives in English) were transcribed in CHAT, the transcription system for the CHILDES Project (MacWhinney 2000). Once transcribed, following Gonçalves et al.'s (2001a, 2001b, 2001c) methodology, the narratives were evaluated according to the dimensions and subdimensions presented in Table 1 (see Garayzábal-Heinze et al. 2012, pp. 63-65; Gonçalves et al. 2011, pp. 292-94 for a detailed explanation of the three dimensions and their analysis).

The narratives produced were evaluated by four linguists specialized in the language acquisition field, and each subdimension, following the original scheme, was evaluated on a 5-value Likert scale ( 1 = very low, 2 =low, 3 = moderate, $4=$ high, 5 = very high). The dependent variable was the mean obtained by the four evaluators for each subdimension (the standard deviation was between 0 and 1.26 for all the subdimensions evaluated).

\section{Results}

Due to the fact that this is a case study involving two participants, a descriptive data analysis was performed. This type of data analysis is the most extended practice within the field due to the recurrent limited number of participants (Garayzábal-Heinze et al. 2012; Feltmate and Bird 2008). I first present an overview of the characteristics of the narratives and then an analysis of the participants' narrative abilities.

\subsection{Characteristics of the Narratives}

Table 3 shows the number of words, the mean length of utterances by words (MLUw), and the Type-token ratio for each of the participants' narratives. These three measures reflect, respectively, the length of the transcribed recording, the participants' linguistic productivity, and their vocabulary variation.

Table 3. Length, mean length of utterances by words (MLUw), and Type-token ratio values for each participant and narrative.

\begin{tabular}{cccccc}
\hline Participant & Session & Production & Words & MLUw & Type-Token Ratio \\
\hline Yves & 1 & A Boy, a Dog and a Frog (English) (Mayer 1967) & 162 & 5.786 & 0.391 \\
Yves & 1 & Frog, Where Are You? (Spanish) (Mayer 1969) & 242 & 6.368 & 0.332 \\
Yves & 2 & A Boy, a Dog and a Frog (Spanish) & 331 & 8.711 & 0.295 \\
Yves & 2 & Frog, Where Are You? (English) & 410 & 7.193 & 0.272 \\
Olivia & 1 & A Boy, a Dog and a Frog (English) & 344 & 11.097 & 0.385 \\
Olivia & 1 & Frog, Where Are You? (Spanish) & 390 & 9.750 & 0.339 \\
Olivia & 2 & A Boy, a Dog and a Frog (Spanish) & 243 & 7.839 & 0.472 \\
Olivia & 2 & Frog, Where Are You? (English) & 301 & 10.379 & 0.409 \\
\hline
\end{tabular}

Overall, Olivia showed better linguistic productivity and richer vocabulary than Yves. However, it is interesting to note that, while in Yves' case the narratives' length and MLUw increase through experience/practice (here understood as a convergence of two factors: the knowledge of the characters and the plot of both stories from session 1 to session 2 and the narrative experience itself acquired between sessions) in both languages, the opposite behavior was detected in Olivia. In her case, the narratives are shorter in both languages in the second session when compared to the first. Another 
opposite trend observed between the two participants is that while Yves' vocabulary richness decreases after experience/practice, the opposite was observed in Olivia, who showed more vocabulary variation in the second session than in the first. As pointed out by an anonymous reviewer, the most feasible explanation for this opposite trend between participants is that while Olivia is more precise when explaining events (higher vocabulary richness and lower extension in session 2), Yves uses more repeated words (higher extension and lower vocabulary richness in session 2). This "repetition strategy" suggests a poor expressive vocabulary, a limitation that previous studies focused on the expressive language of monolingual speakers with PWS have found to a greater or lesser degree (Edmonston 1982; Kleppe et al. 1990; Van Borsel et al. 2007).

\subsection{Narrative Abilities' Analysis}

\subsubsection{Holistic Narrative Performance}

Overall, the results reflect a poorer narrative performance by Yves when compared to Olivia (see Figure 1). While Olivia obtained a global score higher than 50 (maximum score 60) in the four narratives, Yves scored between 31.5 and 35.75 in three narratives (with the exception of the story Frog, Where Are You? (Mayer 1969) narrated in English, where he obtained a score of 46.25 out of 60).

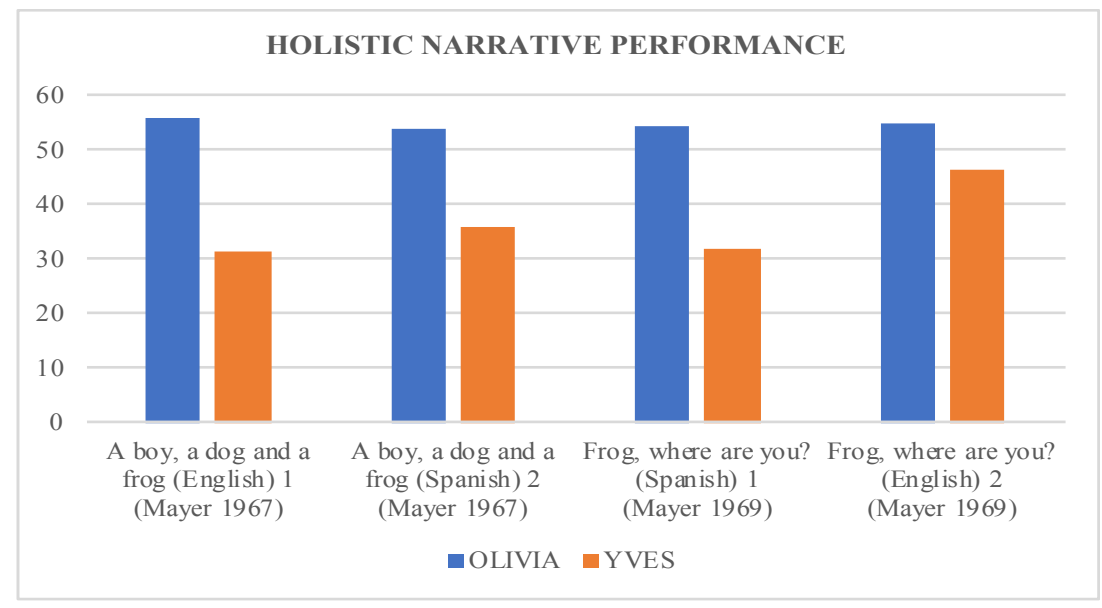

Figure 1. Holistic scores for Olivia and Yves' narrative performance.

\subsubsection{Global Narrative Performance by Dimensions}

Figures 2 and 3 show, respectively, Olivia's and Yves' global performance for the three analyzed dimensions in each of the four narratives. The findings indicate a high and homogeneous command of the three analyzed dimensions in the case of Olivia, as all her scores, regardless of the narrative and the language, were above 15 (maximum score was 20). Yves, on the other hand, showed specific shortcomings. In fact, as Figure 3 reveals, the most problematic areas for the PWS participant were the ones related to the narrative process and complexity and the narrative structure and coherence dimensions since, with the exception of the story Frog, Where Are You? (Mayer 1969) in English, Yves' scores did not exceed 11 points, which is indicative of a poor command of these two dimensions. However, in the case of the narrative content and multiplicity dimension, a slightly better performance was observed as his scores were higher, ranging from 12.75 to 17.25. In what follows, each dimension is analyzed in detail for both Yves' and Olivia's performance. 


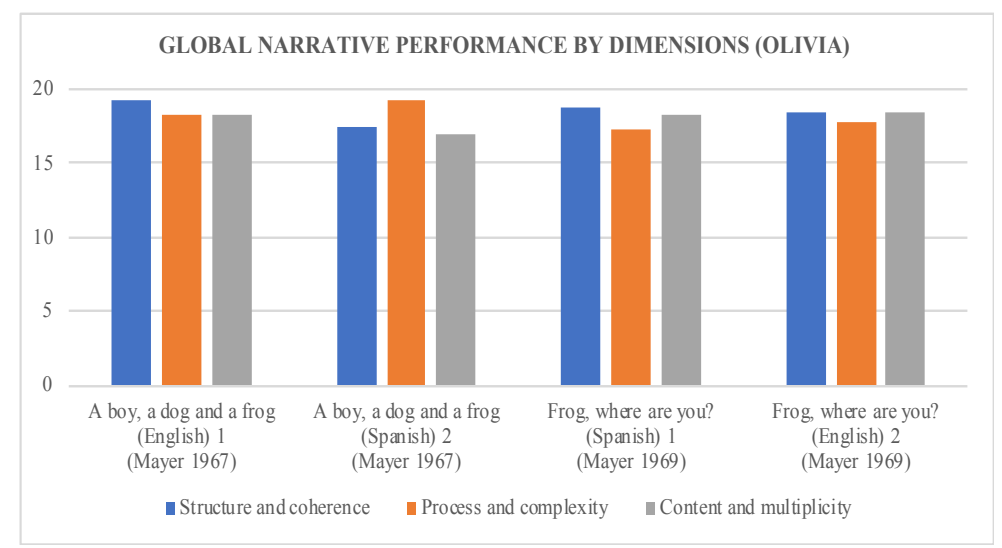

Figure 2. Olivia's global scores by dimensions.

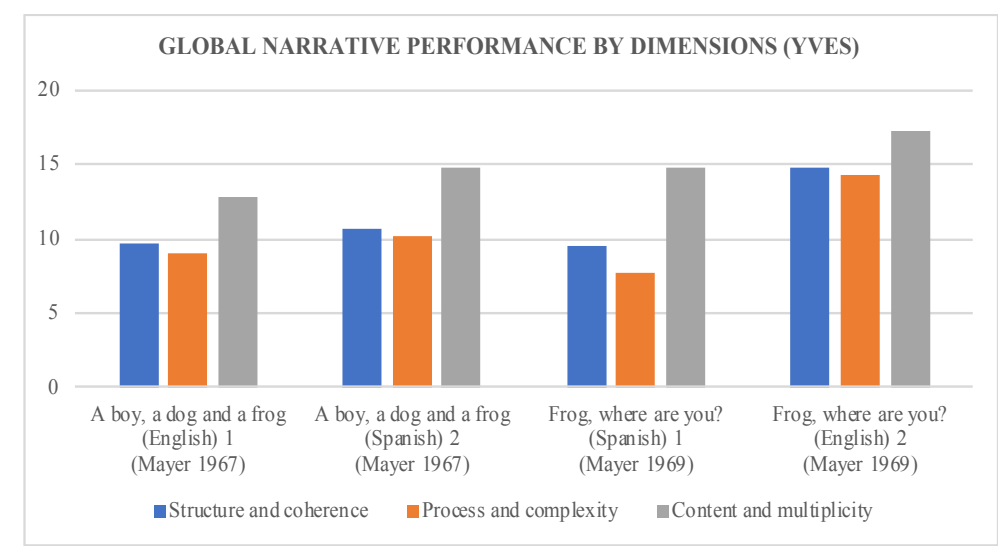

Figure 3. Yves' global scores by dimensions.

\subsubsection{Narrative Structure and Coherence Dimension: Analytic Analysis}

Overall, Olivia performed within the high range (between 4 and 5 points) in all the narrative structure and coherence subdimensions (see Figure 4). Yves, on the other hand, performed within the average-low range (between 2 and 3 points) for all the subdimensions (except in the case of the story Frog, Where Are You? (Mayer 1969) in English, in which he always obtained higher scores as shown in Figure 5). I will delve into this issue with more detail in the discussion section. Globally, it is noteworthy that Yves' lower scores were obtained for the evaluative commitment subdimension, which is indicative of an inability, in this specific case, to get emotionally involved in the narratives.

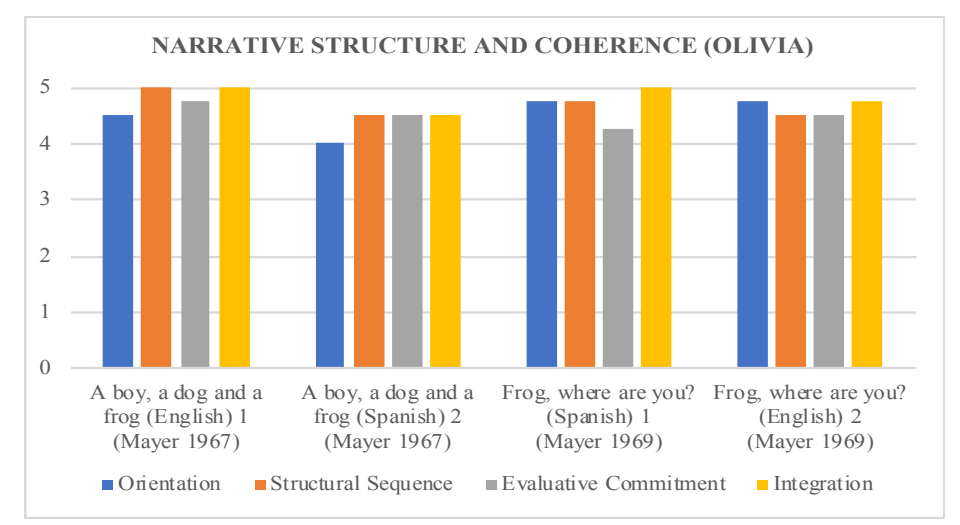

Figure 4. Olivia's scores for the narrative structure and coherence dimension. 


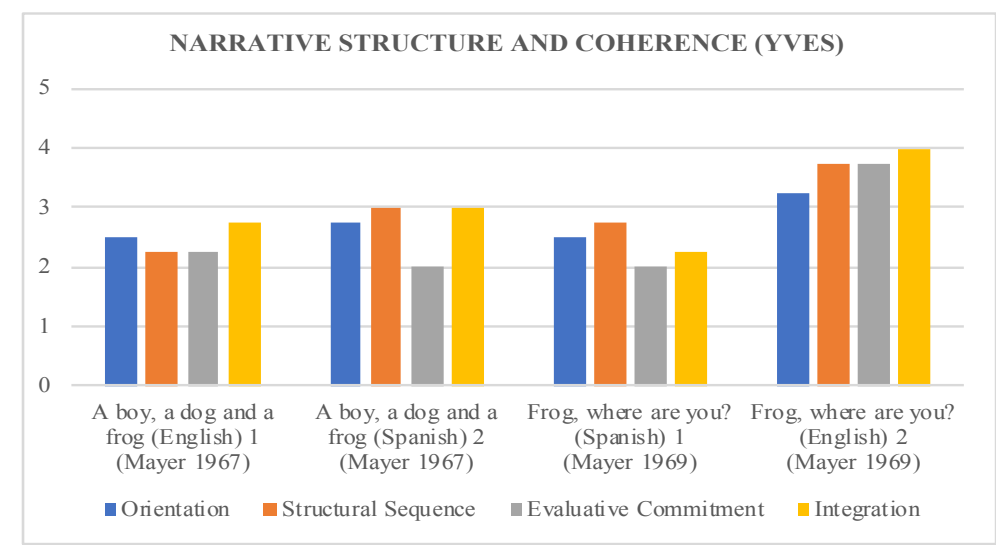

Figure 5. Yves' scores for the narrative structure and coherence dimension.

\subsubsection{Narrative Process and Complexity Dimension: Analytic Analysis}

When focusing on the narrative process and complexity dimension, again, we observe that Olivia performed in the high range for all the subdimensions under analysis (see Figure 6), while Yves, with the exception of the narrative Frog, Where Are You? (Mayer 1969) in English, performed within the average-low range (see Figure 7). In general, Yves' lower scores were obtained when making reference to the cognitive experiences of the different characters (cognitive subjectifying) and when metaphorizing, which is linked to the ability to make inferences.

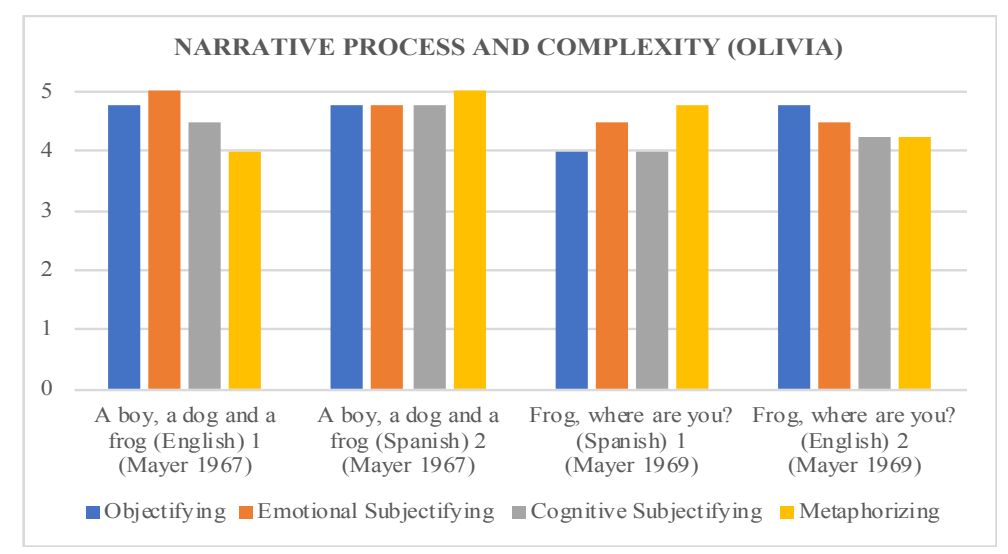

Figure 6. Olivia's scores for the narrative process and complexity dimension.

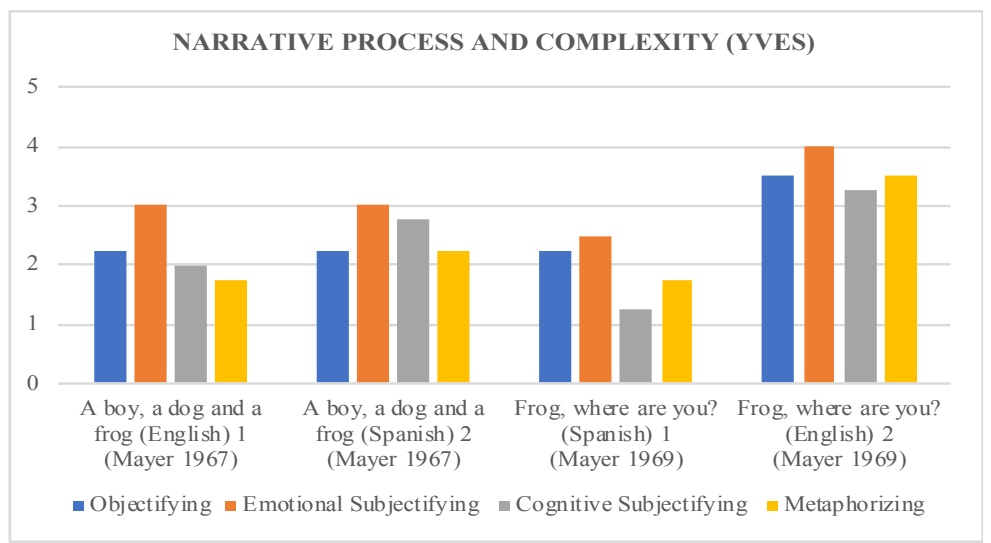

Figure 7. Yves' scores for the narrative process and complexity dimension. 


\subsubsection{Narrative Content and Multiplicity Dimension: Analytic Analysis}

In the narrative content and multiplicity dimension, Olivia performed again within the high range for almost all the subdimensions, since the range of her mean scores were between 3.75 and 5 (see Figure 8). In Yves' case, it is striking that, unlike in the case of the previous dimensions, his scores were, in general, above the 3-point line (see Figure 9), which means at least an average command of the four subdimensions. A more in-depth analysis shows that the specification of characters and events are two of Yves' strengths, since, for these two subdimensions, he performed within the average-high range in all the narratives.

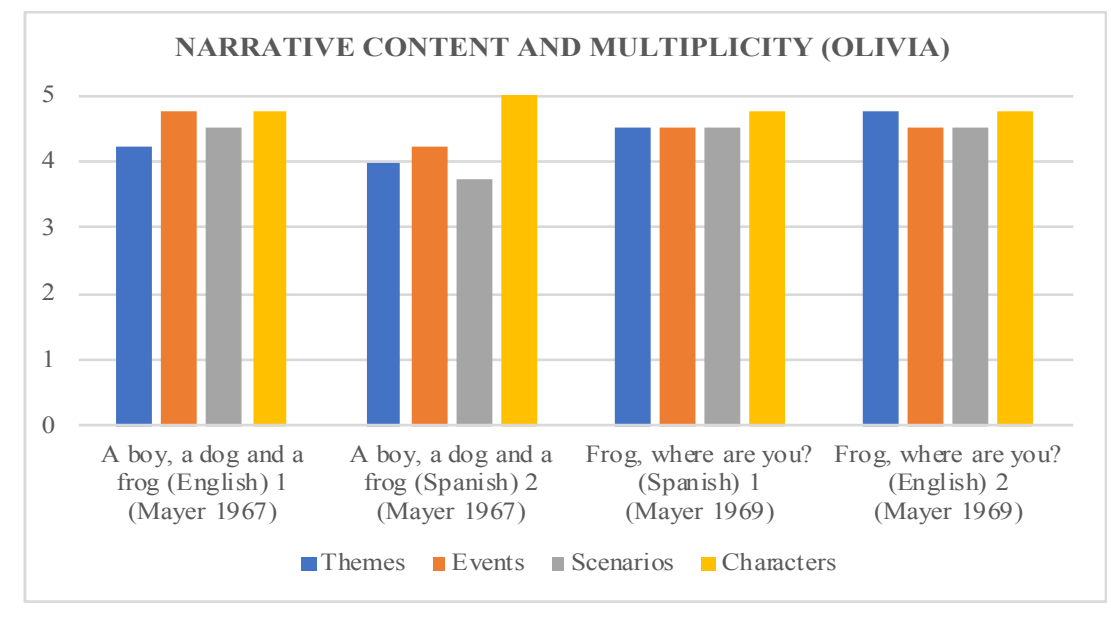

Figure 8. Olivia's scores for the narrative content and multiplicity dimension.

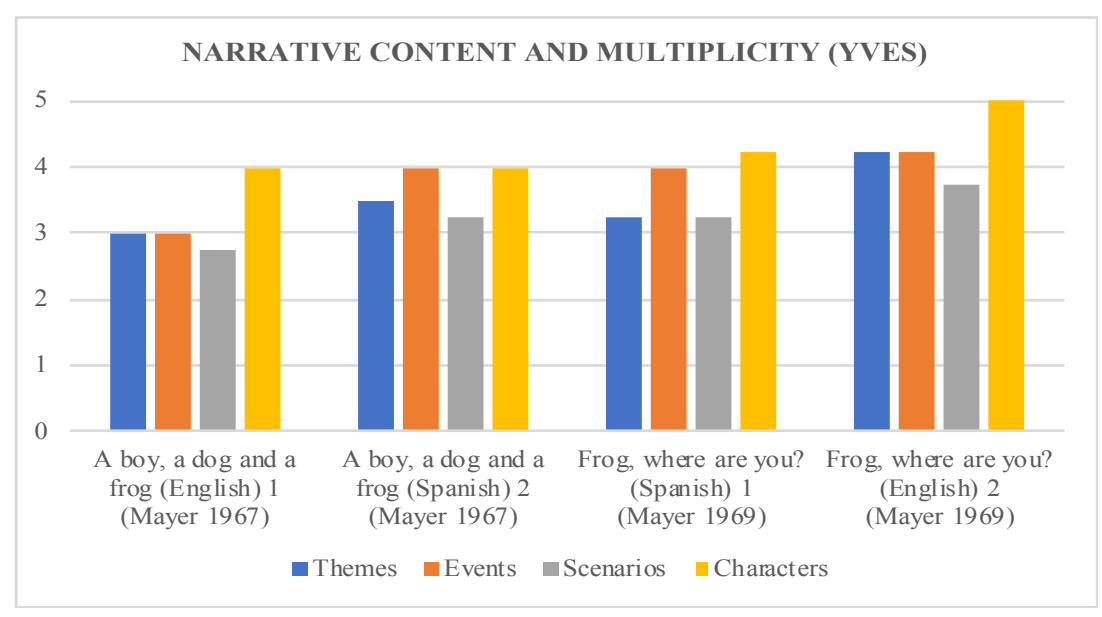

Figure 9. Yves' scores for the narrative content and multiplicity dimension.

\section{Discussion}

The main objective of this study was to analyze the narrative abilities of an English-Spanish bilingual adult with PWS in both languages in comparison to the narratives produced by a TD English-Spanish bilingual adult with a similar sociolinguistic background. Overall, the results showed a rich narrative capacity in both languages for the TD bilingual (Olivia) and a poor performance for the individual with PWS (Yves). Olivia consistently performed within the high range in the four narratives produced (scores higher than 50 out of 60) while Yves' scores reflected an average command (scores between 30-35 points in all the narratives, with the exception of the narrative Frog, Where Are You? (Mayer 1969) in English, in which he obtained 46.25 points). These results showed that Yves' narrative abilities, unlike Olivia's, were lower than what is considered typical development. Thus, this outcome is in line with previous 
findings from studies focused on the narrative abilities of monolinguals with PWS, which consistently demonstrated low narrative quality (Lewis et al. 2002; Garayzábal-Heinze et al. 2012).

When differences between narratives were analyzed, it needs to be noted that while Olivia showed homogeneous narrative abilities in the four narratives produced, a better narrative quality became clear for Yves the second time he narrated a story, regardless of the language variable. As shown in Figure 1, the scores for the two stories presented (A Boy, a Dog and a Frog (Mayer 1967) and Frog, Where Are You? (Mayer 1969)) were higher during the second experimental session. This means that Yves' narrative abilities for A Boy, a Dog and a Frog (Mayer 1967) were slightly superior in Spanish (session 2) than in English (session 1), with a difference of 4.25 points. Similarly, a better performance for the narrative Frog, Where Are You? (Mayer 1969) was observed in English (session 2) than in Spanish (session 1), with a difference of 14.25 points between the narratives in the two languages. This second-time effect indicates that narrative abilities in the PWS individual seem to improve with experience/practice, a finding consistent, to a certain extent, with Lewis et al.'s (2002) results, where older individuals (more experienced) showed better narrative abilities than the youngest ones (less experienced). Also, these results suggest that Yves has a good long-term memory, as has been defended in previous literature on PWS individuals (Curfs et al. 1991; Dimitropoulos et al. 2013), and that this strength, together with the experience/practice gained between the experimental sessions, will potentially make him more confident the second time he performs the task. Consequently, this will lead him to produce, in general terms, richer narratives during the second experimental session within his intrinsic limitations. If we compare Yves' performance between languages and narratives, it is noteworthy that the difference between the English and Spanish narratives is higher when narrating the story Frog, Where Are You? (Mayer 1969). This 10-point difference between the two narratives in the two languages (and between the two sessions) seems to reaffirm the idea that narrative abilities principally improve due to the experience/practice gained, since the story Frog, Where Are You? (Mayer 1969) in English was the last one to be produced. Likewise, the data presented in Table 3 showed that the narratives produced in session two were not only richer in terms of narrative abilities, but also in terms of length, language development (MLUw), and vocabulary variation, although not in the same direction for the two participants in this study. While in session two Yves produced longer narratives and showed a greater MLUw but a less rich vocabulary, Olivia produced shorter narratives richer in terms of vocabulary variation. In light of these preliminary results, both Yves and Olivia showed comparable narrative abilities in Spanish and English. Therefore, bilingualism does not appear to have a negative effect on the development of this PWS bilingual's narrative abilities, a finding that supports Kay-Raining Bird et al.'s (2016) claim that bilingualism among non-TD individuals should not be discouraged.

I will now analyze the results in relation to the three dimensions under study: narrative structure and coherence, narrative process and complexity, and narrative content and multiplicity.

Before delving into each of these three dimensions individually, a global perspective on each one of them is presented. Figures 2 and 3 reflect, respectively, Olivia and Yves' global narrative performance for each dimension and for each narrative. The data showed a consistent narrative control by Olivia in the three analyzed dimensions and different levels of performance in Yves' case. Leaving the story Frog, Where Are You? (Mayer 1969) in English aside (as he probably showed a better command due to the experience/practice acquired), Yves' narrative abilities, in both languages, could be described according to the following scale: narrative content and multiplicity $>$ narrative structure and coherence $>$ narrative process and complexity. In other words, this PWS bilingual showed better narrative abilities when expressing content than when expressing coherence or complexity. Likewise, coherence abilities were slightly superior to the ones attested to express process and complexity. Due to the fact that this is a case study, results should be considered as a first approximation to the analysis of narrative abilities in bilingual speakers with PWS and should, therefore, be interpreted cautiously. However, interestingly enough, Garayzábal-Heinze et al. (2012) also obtained the gradation scale presented above when analyzing the narrative's abilities of two Spanish monolingual adolescents 
with PWS (even though they do not discuss this in their paper). These similar outcomes seem to suggest a tendency that should be confirmed or disproved in future studies including larger samples of monolinguals and bilinguals with PWS. This must by no means be understood as an underestimation of the validity of case study research, whose "power" is often identified as wanting in comparison to large group-based research. Under no circumstances should both approximations be considered opposed but complementary and even necessary in order to have a complete and thorough picture of the phenomenon under analysis. While it is true that large samples and their corresponding statistical analyses provide objective validation to the study, case study research represents, in Flyvbjerg's (2006, p. 228) words, the "force of the example," which is not as valued as it should be taking into account that "more discoveries have arisen from intense observation than from statistics applied to large groups" (Beveridge 1951, quoted here from Flyvbjerg 2006, p. 226).

The following are the results obtained for the three dimensions and their corresponding subdimensions. In the narrative content and multiplicity dimension, Yves performed in the average-high range in all four subdimensions (themes, events, scenarios, and characters) in the four narratives (see Figure 9). This means that Yves' abilities to introduce and change topics (themes), to present different actions (events), to settle the scenario where the narrative takes place (scenarios), and to introduce and involve different characters to the story (characters) were not as impaired as other narrative abilities evaluated in this study. However, if Yves' results are compared to Olivia's performance, some shortcomings are patent. Yves' relative strengths—establishing a sequence of events and incorporating and involving different characters-are illustrated in Example 1 (see Appendixs A and B for complete narrative examples of both participants for the picture book Frog, Where Are You? (Mayer 1969) in Spanish).

Example 1. Yves' final fragment on the Frog, Where Are You? (Spanish) (Mayer 1969).

\begin{tabular}{|c|c|}
\hline Yves' Narrative $^{7}$ & English Translation \\
\hline$[\ldots]$ & {$[\ldots]$} \\
\hline 1. *YVE: \#3 el niño vio a un [//] una mofeta. & 1. *YVE: the boy saw a skunk. \\
\hline 2. *YVE: pero siguió con la colmena. & 2. *YVE: but (he) continued with the hive. \\
\hline 3. *YVE: el \#3 perro tiró la colmena. & 3. *YVE: the dog threw the hive. \\
\hline 4. *YVE: el niño fue a un agujero en el árbol. & 4. *YVE: the boy went to a hole in the tree. \\
\hline 5. *YVE: el búho salió. & 5. *YVE: the owl came out. \\
\hline 6. *YVE: el niño cayó. & 6. *YVE: the boy fell. \\
\hline 7. *YVE: \#4 el perro se escapó de las abejas. & 7. *YVE: the dog escaped from the bees. \\
\hline 8. *YVE: el niño se escondió nel [/] nel búho. & 8. *YVE: the boy hid from the owl. \\
\hline 9. *YVE: \#4 el niño se subió a la roca. & 9. *YVE: the boy climbed the rock. \\
\hline 10. *YVE: y dicho +"/. & 10. *YVE: and (he) said. \\
\hline 11. *YVE: +" y \#3 rana dónde estás. & 11. *YVE: and frog where are you. \\
\hline 12. *YVE: \#4 el niño se subió en un reno. & 12. *YVE: the boy climbed on a reindeer. \\
\hline 13. *YVE: el reno se puso a correr. & 13. *YVE: the reindeer started running. \\
\hline 14. *YVE: \#3 el reno paró. & 14. *YVE: the reindeer stopped. \\
\hline 15. *YVE: y el niño y el perro se cayeron al agua. & 15. *YVE: and the boy and the dog fell into the water. \\
\hline 16. *YVE: \#5 el niño y el perro escucharon. & 16. *YVE: the boy and the dog listened. \\
\hline 17. *YVE: el niño ha dicho al perro que \#4 en silencio. & 17. *YVE: the boy has told the dog that in silence. \\
\hline 18. *YVE: el niño y el perro fueron a ver detrás del tronco. & 18. *YVE: the boy and the dog went to see behind the trunk. \\
\hline 19. *YVE: el niño y el perro encontraron a la rana y su esposa. & 19. *YVE: the boy and the dog found the frog and his wife. \\
\hline 20. *YVE: \#4 el niño y el perro vieron a la familia de la rana. & 20. *YVE: the boy and the dog saw the frog's family. \\
\hline 21. *YVE: el niño y el perro dijeron adiós a las ranas. & 21. *YVE: the boy and the dog said goodbye to the frogs. \\
\hline 22. *YVE: y cogió <un una> [//] un bebé rana. & 22. *YVE: and (he) took a frog baby. \\
\hline @End & @End \\
\hline
\end{tabular}

Leaving structural and coherence issues aside, which will be further discussed later in this section, in this short extract, a good command of events and characters subdimensions was observed. On the

7 The transcription is presented in CHAT, the transcription system for the CHILDES Project, and reflects faithfully what was said by the participant. All syntactic and morphological mistakes are included and they have not been corrected. The narrative is segmented by utterances and the \# + number represents a pause in seconds. 
basis that an event is "a narrative sequence that allows the subject to answer the fundamental narrative question 'what happened?'" (Gonçalves et al. 2001c, p. 6) and that the number of events included in a narrative production determines its quality, among other indicators, it could be said that in the narrative of example 1, Yves showed a relatively rich sequence of events within his narrative limitations, which is translatable to the other narratives he produced. From line 1 to line 22 he presented an event per line, with the exception of line 11, where he reproduced what the child in the story was saying and did not introduce a new action. Similarly, in almost every line, he introduced a new character that was rapidly incorporated into the narrated action. All of the animal characters that were presented played a role-albeit brief-and on no occasion were unfoundedly introduced. These outcomes partially coincide with Garayzábal-Heinze et al.'s (2012) results for monolingual speakers with PWS. On the one hand, both Garayzábal-Heinze et al.'s (2012) and this study reflect an acceptable performance in the themes and events subdimensions. On the other hand, the studies show contradictory results for characters. While Garayzábal-Heinze and collaborators found low scores in monolingual speakers, the present study showed high performance for the bilingual speaker. It is premature to attribute this discordant outcome to a possible bilingualism effect given the limited data handled, but it is an issue that should be studied in depth in future research in order to elucidate whether being bilingual could play a role in this respect. Garayzábal-Heinze et al. (2012, p. 58) attributed the low scores observed in monolingual speakers with PWS when introducing variety of characters to "their behaviour problems, namely aggressiveness, stubbornness, emotional lability, and difficulties in adopting the other point of view." When interpreting Yves' results, we could hypothesize that bilinguals with PWS may show a more social and empathic profile than their monolingual counterparts because of their constant alternation between two languages and two cultures. However, it is worth noting that Yves is passionate about animals and has a high level of "expertise" in different animal species and their characteristics. Consequently, given the fact that the characters in the Frog story series are mainly animals, this could have played a role when it comes to Yves' high scores, since, as previous studies have noted, PWS individuals tend to have obsessions (Cassidy 1997; State et al. 1999). Thus, the alternative hypothesis that Yves' special interest in animals could have "helped" him to enrich his narrative because these characters particularly caught his attention cannot be ruled out at this point. In future research, participants should be presented with stories including either human or non-human characters in order to neutralize a possible character bias.

Focusing on the narrative structure and coherence dimension, Yves, unlike Olivia, performed in the average-low range in all four subdimensions under analysis (see Figure 5) with the exception of the story Frog, Where Are You? (Mayer 1969) in English. This means that handling orientation (contextualization of the story to make it understandable), structural sequence (organization and sequentialization of the story), evaluative commitment (emotional participation of the narrator), and integration (narrating the story in an integrated way) when narrating was hard for Yves. In fact, it seemed to be especially hard for him to get emotionally involved. Example 2 allows us to exemplify Yves' narrative shortcomings in relation to the narrative structure and coherence dimension (see Appendixs C and D for complete narrative examples of both participants for the text A Boy, $a$ Dog and $a$ Frog (Mayer 1967) in English). 
Example 2. Yves and Olivia's initial fragment of the story A Boy, a Dog and a Frog (English) (Mayer 1967).

\begin{tabular}{|c|c|}
\hline Yves & Olivia \\
\hline $\begin{array}{l}\text { 1. *YVE: \#18 the boy and the dog climbed the tree. } \\
\text { 2. *YVE: \#3 so <the frog they ran to the fr }(\mathrm{og})>[/ /] \text { they } \\
\text { ran to catch the frog. } \\
\text { 3. *YVE: they tripped on the branch. } \\
\text { 4. *YVE: they fell in the water. } \\
\text { 5. *YVE: \#5 they landed right beside the frog. } \\
\text { 6. *YVE: \#4 <the frog they tried }>[/ /] \text { the frog jumped. } \\
\text { 7. *YVE: \#4 and landed on a branch. } \\
\text { 8. *YVE: \#5 the boy decided to <put bring the tell> [//] tell } \\
\text { the dog to go to the other side. } \\
\text { 9. *YVE: and he+ll go to the other. } \\
\text { 10. *YVE: \#6 one corner to the frog. } \\
\text { 11. *YVE: \#5 uh the boy caught the dog instead. } \\
\text { 12. *YVE: the frog fell. } \\
\text { 13. *YVE: \#11 the frog was mad. } \\
\text { 14. *YVE: \#7 the boy and the dog said bye to the frog. } \\
\text { 15. *YVE: the frog was sad. } \\
\text { 16. *YVE: \#7 <the frog> [//] the boy and the dog went back } \\
\text { home. [ .. ] }\end{array}$ & $\begin{array}{l}\text { 1. *OLI: \#11 a boy and his dog set out on a fishing trip with a } \\
\text { net and bucket in hand. } \\
\text { 2. *OLI: \#8 the boy and the dog go trekking through the forest } \\
\text { to find the perfect spot to catch a frog. } \\
\text { 3. *OLI: they spot a frog on the pond on top of a lily pad. } \\
\text { 4. *OLI: \#5 and they go running towards the frog with their net } \\
\text { in order to catch the frog. } \\
\text { 5. *OLI: \#4 on their way down the boy and the dog trip on a } \\
\text { uprooted root. } \\
\text { 6. *OLI: and trip. } \\
\text { 7. *OLI: \#6 they trip. } \\
\text { 8. *OLI: and they fall into the pond head first. } \\
\text { 9. *OLI: \#4 and once the boy resurfaces he is face to face with } \\
\text { the frog. } \\
\text { 10. *OLI: \#4 the boy tries to latch onto the frog. } \\
\text { 11. *OLI: but unfortunately the frog jumps \#3 right before he+s } \\
\text { about to catch him. } \\
\text { 12. *OLI: and the frog smirks from a tree trunk not far away. } \\
\text { 13. *OLI: \#6 the boy and the dog scheme. } \\
\text { 14. *OLI: and see what is the best way to catch this frog. } \\
\text { 15. *OLI: and they decide to approach the frog from either side. } \\
\text { 16. *OLI: \#7 and the dog is going to distract the frog while the } \\
\text { boy tries to catch the frog with his net. } \\
\text { 17. *OLI: unfortunately the frog is smart enough. } \\
\text { 18. *OLI: and jumps off the log. } \\
\text { 19. *OLI: and the boy only catches his dog in the net. } \\
\text { 20. *OLI: \#5 the frog is getting angry having to escape the } \\
\text { boy+S net. } \\
\text { 21. *OLI: \#5 and the boy is angry that he hasn+t been able to } \\
\text { catch the frog yet. } \\
\text { 22. *OLI: \#5 so they give up. } \\
\text { 23. *OLI: and they \#2 go home while the frog looks on sadly. } \\
\text { 24. *OLI: \#5 the boy and the dog give up. } \\
\text { 25. *OLI: and head out with their net dragging behind. [ ... ] }\end{array}$ \\
\hline
\end{tabular}

When Yves and Olivia's fragments are compared, the reader will quickly notice the different degree of narrative elaboration and, consequently, the narrative abilities of the two participants. Both fragments reflect the same story passage and it is evident that Olivia's narrative is almost twice as long as Yves', a relevant issue that revealed the position each one took with respect to what information was presented and how. Focusing on orientation, it is worth noting that Olivia clearly situates the reader at the beginning of the story by creating the picture of a boy and his dog being ready to enjoy a fishing day out (lines 1 and 2 of Example 2). Opening by presenting and situating the characters establishes the starting point of the story and situates the recipient of the narration, who, with the information given, will be able to recreate such a scenario in their mind and will be able to model it according to the successive information. On the other hand, Yves did not include an opening description to contextualize the story but started by entering directly into one of the first events included in the story. This makes it very difficult for an interlocutor (who cannot see the picture book and is listening to the story for the first time) to make a proper mental representation of the scenario, since they do not possess the minimal necessary information to recreate it. Likewise, whereas in Olivia's narrative the listener constantly receives explicit and descriptive information that helps them to construct an accurate visual image of the different situations described (e.g., on top of a lily pad in line 3, uprooted root in line 5 or they fall head first in line 8 of Example 2), in Yves' case these clues are practically non-existent, since he concentrated mainly on narrating what happened, without going into greater detail. From a structural sequence point of view, it is important to highlight that Yves' narration is limited to a sequence of events not linked at all by discourse markers (e.g., from line 3 to 14 in Example 1, and from line 3 to 6 in Example 2), or, if linked, by using basic copulative ( $y$ 'and') (e.g., lines 15 and 22 in example 1), adversative (pero 'but') (e.g., line 2 in example 1), or consecutive conjunctions (asi que 'so') (e.g., line 2 Example 2). For the sake of fairness, and although it is true that Olivia's narratives did not include a great deal of discourse markers either, it must be pointed out that 
her level of description and the effective way she connected the information made the recipient feel that they were listening to a detailed and linked-up story (an impression that was not present while listening to Yves' narratives, as he did not integrate the information in a very successful way).

Yves' non-TD-narration-style had a direct impact on his narrative structure and coherence quality evaluation, which translated into low scores for orientation, structural sequence, and integration variables (evaluative commitment will be discussed further). As argued in the previous paragraph, the structure and coherence of Yves' narratives were impaired and required the recipient's predisposition to give the narrative a complete meaning. According to Garayzábal-Heinze et al. (2012), when analyzing the narrative structure and coherence dimension of monolinguals with PWS, they found that PWS individuals were able to identify only the beginning of the story but not the development or ending. The results of this study, however, do not seem to support this claim. According to the data obtained here, the development of the story would be less of a problem for this PWS bilingual than providing an introduction and a closing to the story, since his real challenge seems to lie in the latter outcomes. Yves did not offer evident or strong closure to his narratives (see lines 21 and 22 of Example 1), nor a proper introduction (see lines 1 and 2 of example 2). This seems to favor this PWS individual being described as meticulous and analytical rather than having a holistic or global perspective when narrating. Another interesting issue is Yves' low emotional involvement or commitment in his narratives. Whereas Olivia tended to get emotionally involved in her stories by including evaluation adverbs (see lines 11 and 17 of example 2) and even dared to explain the story A Boy, a Dog and a Frog (Mayer 1967) in Spanish in the first person as if she were the child in the story, Yves adopted a neutral position towards the characters and limited himself to explaining what happened without getting emotionally involved with either the characters or the facts.

When evaluating Yves and Olivia's narrative process and complexity dimension, four subdimensions were analyzed: objectifying (inclusion of sensorial elements), emotional subjectifying (inclusion of emotional states), cognitive subjectifying (cognitive experiences of the characters) and metaphorizing (inclusion of metaphors). As stated before, this was the most impaired dimension in Yves' narratives and, furthering the idea from the previous paragraph, he seemed not to allow his emotions to "interfere" and play an active role in his narrative process. Thus, his narratives were comparatively less complex and diverse than Olivia's. The next step should be to explore in more depth this dimension in future research in order to elucidate whether, within their intrinsic limitations, bilinguals with PWS outperform monolingual speakers in story structure complexity, as Tsimpli et al. (2016) and Baldimtsi et al. (2016) found for bilinguals with SLI and high-functioning autism spectrum disorder, respectively. Overall, Yves scored in the low range in all subdimensions (see Figure 7), with the exception of the emotional subjectifying variable. The only exception to this was in Frog, Where Are You? (Mayer 1969) in English, where he obtained better results in all four dimensions. As a rule, he did not include metaphors and did not provide the reader with a detailed description of the sensorial elements or the characters' thoughts. Nevertheless, he did include some emotional states of the characters (lines 13 and 15 in Example 2), although to a lesser extent and with less detail than Olivia did (see lines 20-23 in Example 2). One possible explanation for the low performance in this dimension could be the idiosyncratic social profile of individuals with PWS, which will condition them to focus primarily on non-social elements (Garayzábal-Heinze et al. 2012). Assuming that this PWS bilingual is more social and empathetic than the PWS monolinguals included in Garayzábal-Heinze et al.'s (2012) study, this more socially oriented attitude would allow him to "socialize" the narratives by including more characters but not delving into more introspective details. Obviously, this possible explanation, as well as the interpretation of other findings and the findings reported in this study, need to be taken cautiously and should be confirmed with more extensive data. 


\section{Conclusions and Implications for Further Research}

To the best of my knowledge, this study is the first to discuss the narrative abilities of an English-Spanish bilingual with PWS in comparison to a TD English-Spanish bilingual. Each participant produced four narratives (two in English and two in Spanish) over two experimental sessions and these narratives were analyzed according to three dimensions: narrative structure and coherence, narrative process and complexity, and narrative content and multiplicity (Gonçalves et al. 2001a, 2001b, 2001c). The results obtained revealed that the bilingual with PWS did not show TD narrative behavior, which is in line with previous studies focusing on the narrative abilities of monolinguals with this syndrome (Lewis et al. 2002; Garayzábal-Heinze et al. 2012).

Another interesting result was that both participants showed comparable narrative abilities in both languages. Thus, a possible interpretation of these results is that bilingualism does not seem to have a negative impact on the development of the narrative abilities of the PWS individual's dominant language, since he is capable of narrating equally in both English and Spanish with the limitations expected from his condition. Therefore, the results from this study do not support the extended practice of denying individuals with PWS access to a second language. Actually, our findings support Kay-Raining Bird et al.'s (2016) defense of promoting bilingualism among non-TD individuals. The limited research carried out within this field has not only proved the ability of these individuals to become bilingual, but has also shown that the second language does not have a negative effect on the development of the first or dominant language. Given that nowadays there exists a tacit agreement among language acquisition researchers to think of bilingualism as an asset rather than a problem, the natural question to be asked is why non-TD individuals, overall, still continue to be denied access to a second language when in fact this access should be facilitated. In future research, it is my intention to test whether, as is the case with TD individuals, bilingual with PWS outperform their monolingual counterparts in different linguistic and non-linguistic abilities.

Another important result was that both participants performed better during the second session of data collection, as is evidenced by their richer narratives. However, this improved performance did not go in the same direction for both participants. While Olivia showed better lexical richness in session two than in session one, Yves exhibited more extended narratives in session two, a greater MLU, and a better control of the narrative abilities in the three analyzed dimensions. This leads to another very interesting finding, which is that while Olivia showed a consistent control of the narrative abilities in the three analyzed dimensions, Yves showed a different level of skillfulness according to the following scale: narrative content and multiplicity $>$ narrative structure and coherence $>$ narrative process and complexity. These results seem to suggest that narrative abilities, which have been revealed as a problematic area for PWS, seem to improve with experience/practice. Therefore, the curricula focused on this population should be carefully oriented towards the development of these abilities in order to make them more effective and, as a consequence, be able to produce "richer" narratives in any or all of the languages they can speak. Research based on the study of bilingualism in non-TD individuals contributes novel data to the field but, more importantly, provides intervention professionals with valuable information that will help them to make informed decisions on how to deal with bilingualism in non-TD bilinguals, as is the case with the PWS bilingual in this study.

Funding: This research was funded by the Ontario Graduate Scholarship program from both the Government of Ontario and the University of Ottawa, by the Excellence Scholarship from the University of Ottawa and by the Doctoral Research Scholarship program from the Fonds de Recherche du Québec-Société et Culture (FRQSC) (Scholarship number: 206102).

Acknowledgments: I would like to thank the two participants of this study for their time and involvement. Also, special thanks are due to the two anonymous reviewers and the editors of this volume for their valuable comments which helped me improve the final version of this manuscript.

Conflicts of Interest: The author declares no conflict of interest. 


\section{Appendix A}

@Begin

@Languages: spa

@Participants: YVE Participant, INV Investigator

@ID: spa | praderwillicorpus | YVE | | | | | Participant | | |

@ID: spa | praderwillicorpus | INV | | | | | Investigator | | |

@ID: spa | praderwillicorpus | YVE | 33;0. I male | nar | | Participant | | |

@Comment: Filename 01spa_yves.cha.

@Situation: Frog where are you in Spanish.

*INV: cuando quieras.

*YVE: \#35 el niño y el perro pusieron la rana <en un> [//] en un \#7 vaso.

*YVE: \#4 el niño y el perro se fueron a dormir.

*YVE: \#5 el perro y el niño despel [//] habían despertado.

*YVE: y vio que la rana se escapó.

*YVE: \#4 perro el niño miraron por todas las partes.

*YVE: \#5 y niño y el perro abrieron la ventana.

*YVE: y [/] \#3 y xxx habían dicho +"/.

*YVE: +" dónde estás rana.

"YVE: el perro se cayó.

*YVE: el niño se enfadó.

*YVE: y el perro dio besos al niño.

*YVE: \#6 luego fueron a un árbol.

*YVE: dijeron + " $/$.

*YVE: +" dónde estás rana.

*YVE: \#4 vinieron [: vieron] un árbol con una <col(mena) oveja> [//] una colmena de ovejas [: abejas].

*YVE: el perro fue la colmena.

*YVE: el niño \#5 dicho +"/.

"YVE: +" dónde se xxx en un agujero.

*YVE: \#3 el niño vio a un [//] una mofeta.

*YVE: pero siguió con la colmena.

*YVE: el \#3 perro tiró la colmena.

*YVE: el niño fue a un agujero en el árbol.

*YVE: el búho salió.

*YVE: el niño cayó.

*YVE: \#4 el perro se escapó de las abejas.

*YVE: el niño se escondió nel [/] nel búho.

*YVE: \#4 el niño se subió a la roca.

"YVE: y dicho + "/.

"YVE: +" y \#3 rana dónde estás.

*YVE: \#4 el niño se subió en un reno.

*YVE: el reno se puso a correr.

*YVE: \#3 el reno paró.

*YVE: y el niño y el perro se cayeron al agua.

*YVE: \#5 el niño y el perro escucharon.

*YVE: el niño ha dicho al perro que \#4 en silencio.

*YVE: el niño y el perro fueron a ver detrás del tronco.

*YVE: el niño y el perro encontraron a la rana y su esposa.

*YVE: \#4 el niño y el perro vieron a la familia de la rana.

*YVE: el niño y el perro dijeron adiós a las ranas.

*YVE: y cogió <un una> [//] un bebé rana. 
@End

\section{Appendix B}

@Begin

@Languages: spa

@Participants: OLI Participant, INV Investigator

@ID: spa | praderwillicorpus | OLI | | | | Participant | | |

@ID: spa | praderwillicorpus | INV | | | | | Investigator | | |

@ID: spa | praderwillicorpus | OLI | 25;0. | female | nar | | Participant | | |

@Comment: Filename 01spa_olivia.cha.

@Situation: Frog where are you in Spanish.

*OLI: el niño Pablo y su perrito están mirando a una rana y es por la noche justo antes de ir+se a la cama.

*OLI: \#4 ya cuando Pablo está durmiendo con su perrito en la cama sale la rana de el jarrón \#3 despacito.

*OLI: y cuando se despierta Pablo se da cuenta que se ha escapa(d)o la rana.

*OLI: \#6 Pablo y su perrito se ponen a buscar por el cuarto a ver si ven dónde se ha ido la rana.

*OLI: pero no le encuentran.

*OLI: buscan en las botas.

*OLI: y no está la rana.

*OLI: \#3 se ponen a llamar a la rana a ver si vuelve a casa.

*OLI: \#5 mientras que llaman a la rana se cae el perrito de la ventana.

*OLI: y se cae afuera.

*OLI: \#4 antes de que se vaya a escapar el perrito también Pablo baja con sus botas puestas.

${ }^{*}$ OLI: y va a coger su perrito a ver si está bien.

*OLI: \#6 y se van a la búsqueda de la rana por afuera.

*OLI: los dos se ponen a llamar a la rana a ver si viene.

*OLI: \#7 Pablo se va hacia el bosque a ver si se ha ido por allí la rana.

*OLI: \#4 miran por todos sitios en abujeros [: agujeros] en la tierra.

*OLI: y llaman a la rana.

*OLI: pero no viene.

*OLI: \#4 en vez de una rana sale una ardilla \#3 que se enfada con Pablo porque le ha estorbido [: estorbado].

*OLI: \#3 Pablo sigue buscando por los árboles a ver si está.

*OLI: y el perrito ha hecho caer un abejorro.

${ }^{*} \mathrm{OLI}$ : \#5 los dos se meten en peligro porque las abejas se ponen a seguir al perrito.

*OLI: y un búho asusta a Pablo.

*OLI: y que le hace caer+se del árbol.

*OLI: \#5 el búho estando enfadado se pone a seguir a Pablo.

*OLI: \#4 Pablo sigue buscando [//] llamando a la rana.

*OLI: pero no sale.

*OLI: \#5 no sale la rana.

*OLI: pero sale un ciervo.

*OLI: \#4 y Pablo se monta al ciervo.

*OLI: y el ciervo se pone a correr.

*OLI: \#3 y justo antes de caer+se de una colina para el ciervo.

*OLI: y se cae Pablo y el perrito \#4 en un lago pequeño.

*OLI: pero parecen que no se han hecho mucho daño.

*OLI: \#5 y siguen buscando a la rana a ver si está en el tronco.

*OLI: y ahí está la rana con su novia.

*OLI: y la rana y la novia han tenido muchos bebés. 
*OLI: \#5 ah no!

*OLI: la rana era hijo de los papás.

*OLI: y ahora se va Pablo con su rana a casa.

@End

\section{Appendix C}

@Begin

@Languages: eng

@Participants: YVE Participant, INV Investigator

@ID: eng | praderwillicorpus | YVE | | | | Participant | | |

@ID: eng | praderwillicorpus | INV | | | | Investigator | | |

@ID: eng | praderwillicorpus | YVE | 33;0. | male | nar | | Participant | | |

@Comment: Filename 01eng_yves.cha.

@Situation: A boy a dog and a frog in English.

*YVE: \#18 the boy and the dog climbed the tree.

*YVE: \#3 so <the frog they ran to the fr(og) $>[/ /]$ they ran to catch the frog.

*YVE: they tripped on the branch.

*YVE: they fell in the water.

*YVE: \#5 they landed right beside the frog.

*YVE: \#4 <the frog they tried $>$ [//] the frog jumped.

*YVE: \#4 and landed on a branch.

*YVE: \#5 the boy decided to <put bring the tell $>$ [//] tell the dog to go to the other side.

*YVE: and he+ll go to the other.

*YVE: \#6 one corner to the frog.

*YVE: \#5 uh the boy caught the dog instead.

*YVE: the frog fell.

*YVE: \#11 the frog was mad.

*YVE: \#7 the boy and the dog said bye to the frog.

*YVE: the frog was sad.

*YVE: \#7 <the frog $>[/ /]$ the boy and the dog went back home.

*YVE: \#15 the frog watched <where they were uh> [//] where the dog and the boy were going.

*YVE: \#6 decided to follow the dog and the boy.

*YVE: \#5 he followed the footprints.

*YVE: \#3 went into the house.

*YVE: \#5 went up the stairs.

*YVE: saw the boy in the tub.

*YVE: \#7 he decided to come to the tub.

*YVE: \#4 and landed on the dog+s head.

${ }^{*} \mathrm{INV}$ : that $+\mathrm{s}$ it.

*INV: that $+\mathrm{s}$ the end?

*YVE: no.

${ }^{*} \mathrm{INV}$ : there are no more slides.

*YVE: oh no?

*INV: no.

*INV: so we are done?

${ }^{*} \mathrm{INV}$ : what $+\mathrm{s}$ the end of the story?

*YVE: \#10 the frog <what> [//] stayed with the boy and dog.

*INV: ok.

*INV: is there something that you want to add?

*YVE: no. 
*INV: no that $+\mathrm{s}$ it.

*INV: ok thank you very much.

@End

\section{Appendix D}

@Begin

@Languages: eng

@Participants: OLI Participant, INV Investigator

@ID: eng | praderwillicorpus | OLI | | | | Participant | | |

@ID: eng | praderwillicorpus | INV | | | | | Investigator | | |

@ID: eng | praderwillicorpus | OLI | 25;0. | female | nar | | Participant | | |

@Comment: Filename 01eng_olivia.cha.

@Situation: A boy a dog and a frog in English.

*OLI: \#11 a boy and his dog set out on a fishing trip with a net and bucket in hand.

*OLI: \#8 the boy and the dog go trekking through the forest to find the perfect spot to catch a frog.

*OLI: they spot a frog on the pond on top of a lily pad.

*OLI: \#5 and they go running towards the frog with their net in order to catch the frog.

*OLI: \#4 on their way down the boy and the dog trip on a uprooted root.

${ }^{*}$ OLI: and trip.

*OLI: \#6 they trip.

*OLI: and they fall into the pond head first.

*OLI: \#4 and once the boy resurfaces he is face to face with the frog.

*OLI: \#4 the boy tries to latch onto the frog.

*OLI: but unfortunately the frog jumps \#3 right before he $+\mathrm{s}$ about to catch him.

*OLI: and the frog smirks from a tree trunk not far away.

*OLI: \#6 the boy and the dog scheme.

*OLI: and see what is the best way to catch this frog.

${ }^{*}$ OLI: and they decide to approach the frog from either side.

*OLI: \#7 and the dog is going to distract the frog while the boy tries to catch the frog with his net.

*OLI: unfortunately the frog is smart enough.

${ }^{*}$ OLI: and jumps off the log.

*OLI: and the boy only catches his dog in the net.

*OLI: \#5 the frog is getting angry having to escape the boy $+\mathrm{s}$ net.

*OLI: \#5 and the boy is angry that he hasn+t been able to catch the frog yet.

*OLI: \#5 so they give up.

*OLI: and they \#2 go home while the frog looks on sadly.

${ }^{*}$ OLI: \#5 the boy and the dog give up.

*OLI: and head out with their net dragging behind.

*OLI: \#4 and the frog is left alone \#3 somewhat lonely.

*OLI: \#3 the frog realizes how lonely he is and how much fun he had with the boy and the dog that he tracks down the pair with their footprints all the way back to their house.

*OLI: \#6 meanwhile the boy is having a bath with his dog to get cleaned upfrom all the day + s adventures.

*OLI: and the frog catches them having a bath.

*OLI: and joins them.

*OLI: \#5 and they all take the bath happily ever after.

@End 


\section{References}

Adesope, Olusola O., Tracy Lavin, Terri Thompson, and Charles Ungerleider. 2010. A Systematic Review and Meta-Analysis of the Cognitive Correlates of Bilingualism. Review of Educational Research 80: 207-45. [CrossRef]

Akefeldt, Arne, B. Akefeldt, and Christopher Gillberg. 1997. Voice, speech and language characteristics of children with Prader-Willi syndrome. Journal of Intellectual Disability Research 41: 302-11. [CrossRef] [PubMed]

Alexander, Randell C., and James W. Hanson. 1988. Overview. In Management of Prader-Willi Syndrome. Edited by Louise R. Greenswag and Randell C. Alexander. New York: Springer, pp. 3-14. [CrossRef]

Anderson, Stephen J., and Martin A. Conway. 1993. Investigating the structure of autobiographical memories. Journal of Experimental Psychology 19: 1178-96. [CrossRef]

Andreou, Maria D. 2015. The Effects of Bilingualism on Verbal and Non Verbal Cognition: The Micro- and Macro-Structure of Narratives in the Weak and the Dominant Language of the Bilingual Child. Unpublished Ph.D. dissertation, Aristotle University of Thessaloniki, Tshessaloniki, Greece, September.

Baker, Colin. 2001. Foundations of Bilingual Education and Bilingualism. Clevedon: Multilingual Matters.

Baldimtsi, Eleni, Eleni Peristeri, Ianthi Maria Tsimpli, and Ageliki Nicolopoulou. 2016. Bilingual Children with High Functioning Autism Spectrum Disorder: Evidence from Oral Narratives and Non-verbal executive Function Tasks. In Proceedings of the 40th Annual Boston University Conference on Language Development. Edited by Jennifer Scott and Deb Waughtal. Somerville: Cascadilla Press, pp. 18-31.

Barke, Ethel M., and D.E. Parry Williams. 1938. A further study of the comparative intelligence of children in certain bilingual and monoglot schools in South Wales. British Journal of Educational Psychology 8: 63-77. [CrossRef]

Bialystok, Ellen. 1999. Cognitive complexity and attentional control in the bilingual mind. Child Development 70: 636-44. [CrossRef]

Bialystok, Ellen. 2001. Against isolationism: Cognitive perspectives on second language research. In The Past, Present, and Future of Second Language Research: Selected Proceedings of the Second Language Research Forum. Edited by Xenia Bonch-Bruevich, William J. Crawford, John Hellermann, Christina Higgins and Hanh Nguyen. Somerville: Cascadilla Proceedings Project, pp. 97-103.

Bialystok, Ellen. 2006. Effect of bilingualism and computer video game experience on the Simon task. Canadian Journal of Experimental Psychology 60: 68-79. [CrossRef] [PubMed]

Bialystok, Ellen, and Fergus I. M. Craik. 2010. Cognitive and linguistic processing in the bilingual mind. Current Directions in Psychological Science 19: 19-23. [CrossRef]

Bialystok, Ellen, Fergus I. M. Craik, Raymond Klein, and Mythili Viswanathan. 2004. Bilingualism, aging and cognitive control: Evidence from the Simon task. Psychology \& Aging 19: 290-303. [CrossRef]

Bialystok, Ellen, Fergus I. M. Craik, and Morris Freedman. 2007. Bilingualism as a protection against the onset of symptoms of dementia. Neuropsychologia 45: 459-64. [CrossRef] [PubMed]

Bishop, Dorothy V. M. 1992. The underlying Nature of Specific Language Impairment. The Journal of Child Psychology and Psychiatry 33: 3-66. [CrossRef] [PubMed]

Bishop, Dorothy V. M. 2006. What Causes Specific Language Impairment in Children? Current Directions in Psychological Science 15: 217-21. [CrossRef] [PubMed]

Branson, C. 1981. Speech and language characteristics of children with Prader-Willi Syndrome. In The Prader-Willi Syndrome. Edited by Vanja A. Holm, Stephen Sulzbacher and Peggy L. Pipes. Baltimore: University Park Press, pp. 179-83.

Bruner, Jerome. 1990. Acts of Meaning. Cambridge and London: Harvard University Press.

Brunner, Edmund. D. 1929. Immigrant Farmers and Their Children. New York: Doubleday, Doran \& Company.

Buiting, Karin, and Bernhard Horsthemke. 2006. Molecular Genetic Findings in Prader-Willi Syndrome. In Management of Prader-Willi Syndrome. Edited by Merlin G. Butler, Philip D. K. Lee and Barbara Y. Whitman. New York: Springer, pp. 58-73. [CrossRef]

Burd, Larry, Barbara Vesely, John Martsolf, and Jacob Kerbeshian. 1990. Prevalence study of Prader-Willi syndrome in North Dakota. American Journal of Medical Genetics 37: 97-99. [CrossRef] [PubMed]

Butler, Merlin G., and Travis Thompson. 2000. Prader-Willi Syndrome: Clinical and Genetic Findings. The Endocrinologist 10: 3S-16S. [CrossRef] 
Carrow, Sister M. A. 1957. Linguistic Functioning of Bilingual and Monolingual Children. Journal of Speech and Hearing Disorders 22: 371-80. [CrossRef] [PubMed]

Cassidy, Suzanne. B. 1997. Prader-Willi syndrome. Journal of Medical Genetics 34: 917-23. [CrossRef] [PubMed]

Cassidy, Suzanne. B., Stuart Schwartz, Jennifer L. Miller, and Daniel J. Driscoll. 2012. Prader-Willi syndrome. Genetics in Medicine 14: 10-26. [CrossRef] [PubMed]

Charman, Tony, Andrew Pickles, Emily Simonoff, Sharon Chandler, Tom Loucas, and Gillian Baird. 2011. IQ in children with autism spectrum disorders: Data from the special needs and autism project (SNAP). Psychological Medicine 41: 619-27. [CrossRef] [PubMed]

Cimolin, Veronica, Manuela Galli, Graziano Grugni, Luca Vismara, Giorgio Albertini, Chiara Rigoldi, and Paolo Capodaglio. 2010. Gait patterns in Prader-Willi and Down syndrome patients. Journal of Neuro Engineering and Rehabilitation 7: 28. [CrossRef] [PubMed]

Cleave, Patricia, Elizabeth Kay-Raining Bird, Natacha Trudeau, and Ann Sutton. 2014. Syntactic bootstrapping in children with Down syndrome: The impact of bilingualism. Journal of Communication Disorders 49: 42-54. [CrossRef] [PubMed]

Cowan, Richard, Chris Donlan, Elizabeth J. Newton, and Delyth Lloyd. 2005. Number skills and knowledge in children with specific language impairment. Journal of Educational Psychology 97: 732-44. [CrossRef]

Cummins, James. 1976. The influence of bilingualism on cognitive growth: A synthesis of research findings and explanatory hypotheses. Working Papers on Bilingualism 9: 1-43.

Curfs, Leopold. M.G., A. Wiegers, Janice Sommers, Martine Borghgraef, and Jean-Pierre Fryns. 1991. Strengths and weaknesses in the cognitive profile of youngsters with Prader-Willi syndrome. Clinical Genetics 40: 430-34. [CrossRef] [PubMed]

Defloor, Truus, John Van Borsel, and Leopold Curfs. 2000. Speech fluency in Prader-Willi Syndrome. Journal of Fluency Disorders 25: 85-98. [CrossRef]

Defloor, Truus, John Van Borsel, Leopold Curfs, and Marc de Bodt. 2001. Aerodynamic and Acoustic Characteristics of Voice in Prader-Willi Syndrome. Journal of Voice 15: 284-90. [CrossRef]

Diaz, Rafael M. 1983. Thought and Two Languages: The Impact of Bilingualism on Cognitive Development. Review of Research in Education 10: 23-54. [CrossRef]

Dimitropoulos, Anastasia, Angela Ferranti, and Maria Lemler. 2013. Expressive and receptive language in Prader-Willi syndrome: Report on genetic subtype differences. Journal of Communication Disorders 46: 193-201. [CrossRef] [PubMed]

Edgin, Jamie O., A. Kumar, Goffredina Spanò, and Lynn Nadel. 2011. Neuropsychological effects of second language exposure in Down syndrome. Journal of Intellectual Disability Research 55: 351-56. [CrossRef] [PubMed]

Edmonston, Nellie K. 1982. Management of speech and language impairment in a case of Prader-Willi syndrome. Language, Speech, and Hearing Services in the School 13: 241-45. [CrossRef]

Emmorey, Karen, Gigi Luk, Jennie E. Pyers, and Ellen Bialystok. 2008. The source of enhanced cognitive control in bilinguals. Evidence from Bimodal Bilinguals. Psychological Science 19: 1201-6. [CrossRef] [PubMed]

Faras, Hadeel, Nahed Al Ateeqi, and Lee Tidmarsh. 2010. Autism spectrum disorders. Annals of Saudi Medicine 30: 295-300. [CrossRef] [PubMed]

Feltmate, Krista, and Elizabeth Kay-Raining Bird. 2008. Language learning in four bilingual children with Down Syndrome: A detailed analysis of vocabulary and morphosyntax. Canadian Journal of Speech-Language Pathology and Audiology 32: 6-20.

Fivush, Robin, and Katherine Nelson. 2004. Culture and language in the emergence of autobiographical memory. Psychological Science 15: 573-77. [CrossRef] [PubMed]

Flyvbjerg, Bent. 2006. Five Misunderstandings about Case-Study Research. Qualitative Inquiry 12: $219-45$. [CrossRef]

Galambos, Sylvia J., and Susan Goldin-Meadow. 1990. The effects of learning two languages on levels of metalinguistic awareness. Cognition 34: 1-56. [CrossRef]

Garayzábal-Heinze, Elena, Magdalena Capó, Esther Moruno, Óscar Gonçalves, Montserrat Fernández, Maria Lens, and Adriana Sampaio. 2012. Uncommon genetic syndromes and narrative production-Case Studies with Williams, Smith-Magenis and Prader-Willi Syndromes? International Journal of Developmental Disabilities 58: 48-65. [CrossRef] 
Gonçalves, Óscar F., Margarida R. Henriques, and Gisela Cardoso. 2001a. Structure and Narrative Coherence Evaluation Manual. Braga: Universidade do Minho.

Gonçalves, Óscar F., Margarida R. Henriques, Alexandra Alves, and Carla Rocha. 2001b. Process and Narrative Complexity Evaluation Manual. Braga: Universidade do Minho.

Gonçalves, Óscar F., Margarida R. Henriques, Luisa Soares, and Anabela Monteiro. 2001c. Narrative Content and Multiplicity Evaluation Manual. Braga: Universidade do Minho.

Gonçalves, Óscar F., Margarida R. Henriques, Alexandra Alves, and Luisa Soares. 2002. Analyzing structure, process and content in narratives of patients diagnosed with agoraphobia. International Journal of Clinical and Health Psychology 2: 389-406.

Gonçalves, Óscar F., Ana P. Pinheiro, Adriana Sampaio, Nuno Sousa, Montse Fernández, and Margarida R. Henriques. 2011. Autobiographical narratives in Williams Syndrome: Structural, process and content dimensions. Journal of Developmental and Physical Disabilities 23: 289-302. [CrossRef]

Greenswag, Louise R., and Randell C. Alexander. 1988. Management of Prader-Willi Syndrome. New York: Springer. [CrossRef]

Hakuta, Kenji, and Rafael M. Diaz. 1985. The relationship between degree of bilingualism and cognitive ability: A critical discussion and some new longitudinal data. In Children's Language. Edited by Keith E. Nelson. Hillsdale: Erlbaum, vol. 5, pp. 319-44.

Harris, Chester W. 1948. An exploration of language skill patterns. Journal of Educational Psychology 32: 351-64. [CrossRef]

Hick, Rachel, Nicola Botting, and Gina Conti-Ramsden. 2005. Cognitive abilities in children with specific language impairment: Consideration of visuo-spatial skills. International Journal of Language \& Communication Disorders 40: 137-49. [CrossRef]

Kay-Raining Bird, Elizabeth, Patricia L. Cleave, Natacha Trudeau, Elin Thordardottir, Ann Sutton, and Amy Thorpe. 2005. The language abilities of bilingual children with Down syndrome. American Journal of Speech-Language Pathology 14: 187-99. [CrossRef]

Kay-Raining Bird, Elizabeth, Fred Genesee, and Ludo Verhoeven. 2016. Bilingualism in children with developmental disorders: A narrative review. Journal of Communication Disorders 63: 1-14. [CrossRef] [PubMed]

Kleppe, Sallie A., Kerri Misaki Katayama, Kenneth G. Shipley, and David R. Foushee. 1990. The speech and language characteristics of children with Prader-Willi Syndrome. Journal of Speech and Hearing Disorders 55: 300-9. [CrossRef] [PubMed]

Kohnert, Kathryn, and Amelia Medina. 2009. Bilingual children and communication disorders: A 30-year research retrospective. Seminars in Speech and Language 30: 219-33. [CrossRef] [PubMed]

Koriakin, Taylor A., Mark D. Mccurdy, Aimilia Papazoglou, Alison E. Pritchard, T. Andrew Zabel, E. Mark Mahone, and Lisa A. Jacobson. 2013. Classification of intellectual disability using the Wechsler Intelligence Scale for Children: Full Scale IQ or General Abilities Index? Developmental Medicine and Child Neurology 55: 840-45. [CrossRef] [PubMed]

Lewis, Barbara A. 2006. Speech and Language Disorders Associated with Prader-Willi Syndrome. In Management of Prader-Willi Syndrome. Edited by Merlin G. Butler, Philip D. K. Lee and Barbara Y. Whitman. New York: Springer, pp. 272-83. [CrossRef]

Lewis, Barbara A., Lisa Freebairn, Shauna Heeger, and Suzanne B. Cassidy. 2002. Speech and language skills of individuals with Prader-Willi syndrome. American Journal of Speech-Language Pathology 11: 285-94. [CrossRef]

MacWhinney, Brian. 2000. The CHILDES Project: Tools for Analyzing Talk, 3rd ed. Mahwah: Lawrence Erlbaum Associates.

Mainela-Arnold, Elina, Martha W. Alibali, Kristin Ryan, and Julia L. Evans. 2011. Knowledge of mathematical equivalence in children with specific language impairment: Insights from gesture and speech. Language, Speech, and Hearing Services in Schools 42: 18-30. [CrossRef]

Mayer, Mercer. 1967. A Boy, a Dog and a Frog. New York: Dial Press.

Mayer, Mercer. 1969. Frog, Where Are You? New York: Dial Press.

Morales, Julia, Alejandra Calvo, and Ellen Bialystok. 2013. Working memory development in monolingual and bilingual children. Journal of Experimental Child Psychology 114: 187-202. [CrossRef] [PubMed]

Munson-Davis, Joyce A. 1988. Speech and Language Development. In Management of Prader-Willi Syndrome. Edited by Louise R. Greenswag and Randell C. Alexander. New York: Springer, pp. 124-33.

Paradis, Johanne, Fred Genesee, and Martha Crago. 2011. Dual Language Development and Disorders: A Handbook on Bilingualism and Second Language Learning. Baltimore: Paul H Brookes. 
Parker, Matthew, and Kent Brorson. 2005. A comparative study between mean length of utterance in morphemes (MLUm) and mean length of utterance in words (MLUw). First Language 25: 365-76. [CrossRef]

Peal, Elizabeth, and Wallace E. Lambert. 1962. The relation of bilingualism to intelligence. Psychological Monographs 76: 1-23. [CrossRef]

Perovic, Alexandra, and Solene Lochet. 2015. Grammatical morphology in bilingual Williams syndrome: A single case study. Paper presented at Bi-SLI 2015, Tours, France, July 2-3.

Prader, Andrea, Alexis Labhart, and Heinrich Willi. 1956. Ein Syndrome von Adipositas, Kleinwuchs, Kryptochismus und Oligophrenie nach myatonieartigem Zustand in Neugeborenenalter. Schweizerische Medizinische Wochenschrift 86: 1260-61.

Ransdell, Sarah, Marie-Laure Barbier, and Toomas Niit. 2006. Metacognitions about language skill and working memory among monolingual and bilingual college students: When does multilingualism matter? International Journal of Bilingual Education and Bilingualism 9: 728-41. [CrossRef]

Ricciardelli, Lina A. 1992. Creativity and bilingualism. Journal of Creative Behavior 26: 242-54. [CrossRef]

Sanz-Torrent, Mònica, Elisabet Serrat, Llorenç Andreu, and Miquel Serra. 2008. Verb morphology in Catalan and Spanish in children with Specific Language Impairment: A developmental study. Clinical Linguistics and Phonetics 22: 459-74. [CrossRef] [PubMed]

Serra, Miquel, Elisabet Serrat, Rosa Solé, Aurora Bel, and Melina Aparici. 2000. Adquisición del Lenguaje. Barcelona: Ariel.

Seung, HyeKyeung, Siraj Siddiqi, and Jennifer H. Elder. 2006. Intervention outcomes of a bilingual child with autism. Journal of Medical Speech-Language Pathology 14: 53-63.

Slobin, Dan I. 2005. Relating narrative events in translation. In Perspectives on Language and Language Development: Essays in Honor of Ruth A. Berman. Edited by Dorit Ravid and Hava Bat-Zeev Shyldkrot. Dordrecht: Kluwer, pp. 115-29. [CrossRef]

State, Matthew W., Elisabeth M. Dykens, Beth Rosner, Andres Martin, and Bryan H. King. 1999. Obsessive-compulsive symptoms in Prader-Willi and "Prader-Willi-like" patients. Journal of the American Academy of Child \& Adolescent Psychiatry 38: 329-34. [CrossRef]

Strömqvist, Sven, and Ludo Verhoeven. 2004. Relating Events in Narrative: Typological and Contextual Perspectives. Mahwah: Lawrence Erlbaum Associates.

Tager-Flusberg, Helen. 2004. Do Autism and Specific Language Impairment Represent Overlapping Language Disorders? In Developmental Language Disorders. From Phenotypes to Etiologies. Edited by Mabel L. Rice and Steven F. Warren. Mahwah: Lawrence Erlbaum Associates, pp. 31-53. [CrossRef]

Thomas, Jaqueline. 1992. Metalinguistic awareness in second-and third-language learning. In Cognitive Processing in Bilinguals. Edited by Richard J. Harris. Amsterdam: North Holland, pp. 531-45. [CrossRef]

Trudeau, Natacha, Elizabeth Kay-Raining Bird, Ann Sutton, and Patricia L. Cleave. 2011. Développement lexical chez les enfants bilingues avec Trisomie 21 [Lexical development in bilingual children with Down syndrome]. Enfance 2011: 383-404. [CrossRef]

Tsimpli, Ianthi M., Eleni Peristeri, and Maria Andreou. 2016. Narrative production in monolingual and bilingual children with specific language impairment. Applied Psycholinguistics 37: 195-216. [CrossRef]

UCLES. 2001. Quick Placement Test. Oxford: Oxford University Press.

Vallar, Giuseppe, and Costanza Papagno. 1993. Preserved vocabulary acquisition in Down's syndrome: The role of phonological short-term memory. Cortex 29: 467-83. [CrossRef]

Van Borsel, John, Tom Defloor, and Leopold M. G. Curfs. 2007. Expressive Language in persons with Prader-Willi Syndrome. Genetic Counseling 18: 17-28. [PubMed]

Wisconsin Spanish Placement Test. 2009. Madison: University of Wisconsin.

Woll, Bencie, and Nicola Grove. 1996. On language deficits and modality in children with Down syndrome: A case study of twins bilingual in BSL and English. Journal of Deaf Studies and Deaf Education 1: 271-78. [CrossRef] [PubMed]

Yelland, Gregory W., Jacinta Pollard, and Anthony Mercuri. 1993. The metalinguistic benefits of limited contact with a second language. Applied Psycholinguistics 14: 423-44. [CrossRef]

(C) 2018 by the author. Licensee MDPI, Basel, Switzerland. This article is an open access article distributed under the terms and conditions of the Creative Commons Attribution (CC BY) license (http:/ / creativecommons.org/licenses/by/4.0/). 